\title{
Mahkûmların Bilgi Gereksinimleri ve Bilgi Davranışları: Kuramsal Bir Değerlendirme
}

\section{Information Needs and Information Behaviors of Prisoners: A Theoretical Evaluation}

\section{Güler Demir*}

\section{$\ddot{\boldsymbol{z}_{z}}$}

Fiziksel, zihinsel, çevresel, sosyoekonomik, kültürel ve benzeri nedenlerle bilgi kaynaklarından yararlanmaları sınırlanan kişi ve grupların bilgi gereksinim ve davranışları bu sinırlılıklar bağlamında dikkate alınmalıdır. Bu çalışmanın amacı, anılan gruptaki mahkûmların bilgi gereksinimleri, bilgi davranışları ve bu bağlamda etken olan faktörler ile karşılaşılan sorunlara ilişkin kuramsal bir çerçeve oluşturmaktır. Çalışmada betimleme yöntemi kullanılmış, yerli literatürün sınırlılı̆̆ı nedeni ile daha çok yabancı literatür taranarak genel çerçevede bilgi davranışlarına ilişkin olgu, kavram ve yaklaşımlar, özel olarak da mahkûmların bilgi gereksinimi ve davranışları ile onları biçimlendiren etmenler araştırılmış ve irdelenmiştir. Çalışmanın sonunda, mahkûmların bilgi gereksinimi ile davranışlarının özgür vatandaşlarınkilerle benzerlik gösterse de cezaevi (ve/veya tutukevi) ortam ve koşullarının etkisiyle biçimlenen özel, sınırlı ve sorunlu karakteristikleri olduğu sonucuna varılmıştır.

Anahtar Sözcükler: Bilgi gereksinimi; bilgi arama davranışı; bilgi davranışı; Wilson modeli; mahkûmlar; dezavantajll/yoksun gruplar; cezaevi; cezaevi kütüphanesi.

\begin{abstract}
Information behaviors of individuals and groups who have limited access to information sources due to various reasons such as physical, mental, environmental, socio-economic, cultural, etc. should be considered vitally important in the context of the aforementioned limitations. This study aims to provide a theoretical framework regarding the information needs, information behaviors of the prisoners who are categorized in that group and to provide insight into the effective factors in this context as well as the problems faced by these groups. Within the scope of the study in which descriptive method is used, first, in a general context, features, concepts, and approaches related to information behaviors, and then specific information needs and behaviors of prisoners and the factors that shape them are discussed. Due to the limited researches that have been conducted in the related area in the domestic literature, foreign literature is consulted mainly. As a result, it is concluded that although the information needs and behaviors of the prisoners have similarities with those of free citizens,
\end{abstract}

\footnotetext{
* Doç. Dr., Kastamonu Üniversitesi Bilgi ve Belge Yönetimi Bölümü. E-posta: gulerdemir2009@gmail.com Associate. Prof., Kastamonu University Department of Information and Records Management, Turkey
} 
they have special, limited and problematic characteristics shaped by the effect of prison (and/or detention) environment and conditions.

Keywords: Information need; information seeking behavior; information searching behavior; information behavior; Wilson model; prisoners; inmates; incarcerates; disadvantaged groups; prison; jail; prison library.

\section{Giriş}

Yaşam biçimimizi belirlemeye ilişkin beceriler ve bu konuda tercih hakkımız bizim için çok önemlidir. Ancak mahkûmiyet durumu söz konusu olduğunda, bu hak sinırlanmaktadır. Mahkûmların temel insani gereksinimleri diğer insanlarınkinden farklı değildir. Maslow tarafından önerilen hiyerarşik çerçevede nasıl ki hiyerarşinin temelinde "temel" fiziksel gereksinimler yer alıyorsa, mahkûmların durumu da benzer çerçevede değerlendirilmelidir. Mahkûmlar için bu hiyerarşi, temelde barınma, orta katmanlarda çalışma ve eğitim ile üst katmanlarda diğerlerine karşı tavır ve tutumlar biçiminde oluşturulabilir. Söz konusu gereksinimlerin hepsi birbiri ile etkileşimli olduğu için onları birbirinden ayırmak yanlış sonuçlar doğurabilir. Örneğin bazı mahkûmlarda depresyon ile madde bağımlılığı ilişkili olurken bazılarında evsizlik, eksik eğitim ve düşük gelir depresyon için risk faktörü olabilmektedir. Cezaevi ortamına giren kişi için pek çok tercih hakkı ortadan kalkmakta, gereksinimlerin giderilmesi kontrollü bir yapıya bürünmektedir. Mahkûmların, yıkanma, giyinme, uyuma, neyi ne zaman yiyeceğini seçme gibi en temel insani işlevleri dahi kendi tercih sınırlarının dışına çıkmaktadır. Mahkûmlar, bütün bu çok sıradan görülen ama aslında çok önemli davranışlar üzerindeki kontrol hakkını kaybetmektedirler. Çocuklukta doğal olan bu kontrol altına alınma deneyimleri yetişkinlik için şok etkisi yaratan ağır bir durumdur. $\mathrm{Bu}$ etkenler, öfke, düş kırıklığı, şaşkınlık, ajitasyon, umutsuzluk veya depresyon gibi her türden reaksiyona yol açabilmektedir. Özellikle cezaevi koşullarına ilk kez maruz kalan mahkûmlar bu durumu aşağılayıcı ve korkutucu bulmaktadır (Cooke, Baldwin ve Howison, 1993, s. 55-56; Crighton ve Towl, 2008, s. 58-59). Mahkûmiyetin kültürel boyutları ile ilgili çalışmaların öncüsü olan Clemmer tarafindan türetilen "prisonization" (cezaevileşme) kavramı ile bu ortamın kendine özgü kültürüne ilk kez vurgu yapılmıştır. Cezaevi alt kültürüne atıf yapan bu kavram ile cezaevi koşullarının oluşturduğu adet, alışkanlık, gelenek, tavır, tutumlara, kısacası genel olarak cezaevi alt kültürüne işaret edilmektedir (Clemmer, 1940, s. 270; akt. Paterline ve Orr, 2016, s. 70). Cezaevi yaşamının doğal olmayan, anormal koşulları ile beraber söz konusu alt kültürün mahkûmun yaşamında oluşturduğu tüm değişiklikler -psikolojik bileşenleri de dâhil- tepki olarak bir tür baş etme (coping) ve adaptasyon süreci ile biçimlenmektedir. Şüphesiz bu adaptasyon, mahkûmun önceki cezaevi deneyimleri, maruz kaldığı ortamlar vb. değişkenlere bağlı olarak mahkûmdan mahkûma değişebilmektedir (Haney, 2012, s. 4). Bununla beraber hapis cezası süreçlerinin özellikle başlangıçta önemli oranda psikolojik rahatsızlıklara neden olduğu ancak bu rahatsızlıkların cezaevi ortamının sabit, değişmeyen yapısına alışıldıkça yavaş ve kademeli bir iyileşmenin de oluştuğu bilinmektedir. Ancak bu iyileşme hapis olma sürecinden kaynaklanan bazı acıları hafifletebilse ve mahkûm için bir tür uyarlanma süreci olsa dahi aslında yalnızca cezaevinin olumsuz etkilerini maskelemektedir (Zamble, 1992, s. 420; Haney, 2012, s. 5). Mahkûmu mahkûmiyet sonrası yaşama hazırlamak dikkate alınması gereken bir diğer önemli konudur çünkü serbest bırakılma durumunda dış 
dünyaya uyum çok kolay gerçekleşememektedir. Clark ve Erica (2006, s. 1-2) tarafından işaret edildiği gibi, kısa süreli mahkûmiyet yaşayanların serbest kaldıkları zaman dış dünyaya tekrar uyum sağlamaları uzun süreli mahkûmiyet yaşayanlara göre daha kolaydır. Uzun süre mahkûmiyet yaşayıp serbest kalanlar, dış dünyada kanıksanmış olan pek çok teknolojik ürün ve olanağı (ATM'ler, internet, cep telefonları, iPod'lar vb.) henüz yeterince benimsememiş, deneyimlememiştir. Bunun gibi, aile ve yakınlar ile tekrar bağ kurma, yeniden iş yaşamına girme gibi pek çok konuda uyum sorunu oluşmaktadır

Tüm bu bilgilerin ışığında gerek cezaevi ortamı ve koşullarının kurallarla sınırlı yapısına ve kendine özgü (cezaevi) kültürüne, gerekse mahkûmiyet sonrasında dış dünyaya uyumun mahkûmlar için kolay olmadığını söyleyebiliriz. Mahkûmun, cezaevinin olumsuzluklar oluşturabilen bu etkilerinden olası en düşük ölçüde etkilenmesi ve cezaevi sonrasındaki yaşamına hazırlanması için uygulanan rehabilitasyon program ve uygulamaları oldukça önemlidir. Rehabilitasyon, mahkûmların yaşamlarını iyileştirerek topluma başarılı biçimde yeniden katılmalarına yardımcı olur. Örneğin mahkûmlar için geliştirilen eğitim programları ile mesleki eğitimin mahkûmiyetten sonra iş olanakları ve başarısını artırabildiğine ve tekrar suç işleme olasılığını ortadan kaldırabildiğine dair kanıtlar bulunmaktadır. Bunun gibi, zihinsel sağlık veya madde bağımlılığına ilişkin sorunları ele alan hizmetler de tekrar suç işleme eğilimini azaltabilmektedir (Ploch, 2012, s. 892).

Mahkûmlar, cezaevinde bulundukları süre içinde, dışarıdaki bilimsel, teknolojik, ekonomik, sosyal vb. anlamlarda alanlarda çok çeşitli değişim ve dönüşümlerden uzakta kalırlar. Dış dünya ile aralarında oluşan bu boşluğun giderilmesi için gereken bilgi ve becerileri kazandırmaya odaklanan rehabilitasyon programları oldukça önemlidir. Pek çok mahkûmun önemli düzeyde fonksiyonel okuryazar olmadığı, öğrenme ve bilgi edinmeye ilişkin güçlükler çektiği, bilgi ve becerilerinin eksik olduğu bilinmektedir. Mahkûmların bu ve benzeri sorunlarının giderilmesi, etkin bilgi ortamlarına ulaşabilmelerine olanak sağlanması gibi konularda rehabilitasyon programları özenle hazırlanmalıdır. Bu programlar, mahkûmların gelecekleri hakkında doğru kararlar verebilmeleri için bilgi ve destek almalarına, gelecekteki yaşamları, istihdamları vb. konularda gerekli becerileri geliştirmeye odaklanmalıdır. Etkin bilgi erişim ve destek yöntemleri ile olanakları, bu tür programların odağı olarak kabul edilmektedir (Ministry of Justice, 2011, s. 5; Learning \& Work Institute, 2018; Canning ve Buchanan, 2019, s. 418). Mahkûmlara bilgi erişimi ve desteği (temel okuryazarlık sınıflarından açık üniversite kurslarına kadar) öncelikle cezaevi kütüphaneleri de dâhil cezaevi öğrenme merkezleri/sistemleri aracılığıyla sağlanabilir. Bu erişim ve destek süreçleri, mahkûmların bilgi gereksinimleri ve davranışlarının anlaşılması bağlamında önemlidir. Cezaevi bilgi hizmetlerinin gereken oranda sağlanmaması ya da mahkûmların bu hizmetlerden yararlanmaması, mahkûmların bilgi gereksinimleri ve davranışlarının yeterince anlaşılmamasını tetikleyen bir durumdur (Canning ve Buchanan, 2019, s. 418). Cezaevi dışındaki/dış dünyaya ilişkin bilgi kaynaklarına erişimin olmadığı bir ortamda, cezaevi kütüphanesi mahkûmların bilgi gereksinimlerini karşılamada büyük yarar sağlama potansiyeline sahiptir. Bu aynı zamanda çoğunlukla tek seçenektir (Garner, 2017a, s. 336).

Bireylerin bilgi gereksinimi ve davranışlarının arka planında, yaş, ruhsal ve bilişsel durum, eğitim düzeyi, sosyal statü, yaşanılan yer, aile ve yakın çevre, toplum, sosyokültürel yapı, eğitim sistemi ve pek çok etmen yer almaktadır. Anılan etmenlerle beraber, cezaevi ortam 
ve koşulları göz önüne alındığında, mahkûmların bilgi davranışlarının kendine özgü bir nitelik oluşturması doğal bir sonuçtur.

\section{Literatür Değerlendirmesi: Bilgi Gereksinimi ve Bilgi Davranışı}

Bilgi arama araştırmalarının tarihsel kökleri 1916 yılına kadar gitmektedir (Ayres ve McKinnie, 1916; akt. Wilson, 2000, s. 50; Çakmak, 2016, s. 47). Wilson (2000, s. 50) tarafından verilen bilgilere göre, bu bağlamda çalışmaların hızlanması ise 1920 ve 30'lu yılları bulmuştur. İlk araştırmalar, daha çok kütüphane kullanımı ile ilgili olup insanları bilginin kaynağı olan kütüphaneye yönlendiren bilgi gereksinimlerine sınırlı oranda işaret edilmektedir. Kullanıcının sosyal sınıf yapısı ve kültürel arka planı gibi konuların ise daha yüksek oranda ilgi konusu olduğu anlaşılmaktadır (Wilson, 2000, s. 50). Esasen bilgi arama araştırmaları "enformasyon bilimi" (information science) teriminin keşfinden de önceki tarihlerden başlayarak bilgi bilimcilerin zihinlerini meşgul etmiştir. Bu bağlamda, tarihsel süreçte 1948'de gerçekleştirilen Kraliyet Derneği Bilimsel Bilgi Konferans1 da (Royal Society Scientific Information Conference) özel bir yer tutar (Wilson, 1999, s. 250). Konferansin önemli bir amac1, bilgi hizmetlerinin bilimsel kullanıcı bakış açısıyla değerlendirilmesine zemin sağlamaktır. Bu konferansa temel ve esin olan bir diğer konferans, daha önce (1946) yapılan ve konu ile ilgili çeşitli önerilerin sunulduğu bir diğer konferanstır (Royal Society Empire Conference) (McNinch, 1949, s. 136-137).

Bilgi arama davranışları, kullanıcı araştırmalarında belli başı bir yere sahip olduğundan, tarihinin de bilimsel iletişim ve bilgi kullanımı ile ilgili ilk çalışmalara dayandığı düşünülebilir. Doğal bir sonuç olarak kavramın kullanımı, bu alandaki gelişmelere koşut olarak değişmiştir. Bilgi arama davranışına ilişkin yapılan ilk referanslar, bilim insanlarının resmi ve gayri resmi iletişim kanallarına vurgu yapar. Bilim insanlarının bilgi arama davranışı ifadesi ile tipik olarak, meslektaşlarına danışan, dergi, kitap, öz (abstract) ve dizin hizmetlerini kullanan, yayınların baskı öncesi ya da yeniden basım versiyonlarını elde eden, konferanslara katılan kişilerin eylemlerine atıf yapılmaktadır (Ellis, 2003, s. 300-301).

Bilgi sistemleri kullanıcılarını ve bilgi gereksinimlerini inceleyen ilk uluslararası yayınlar 20. yüzyılın başlarında ortaya çıkmıştır. Ancak, 1960'lı yıllara kadar, bilgi arama sürecine kullanıcının bakış açısından yaklaşan pek fazla çalışmaya rastlanmamaktadır. 1960'lı yıllardan sonra yapılan çalışmalar, kullanıcı odağına doğru eğilimin yavaş yavaş geliştiği yıllardır (González-Teruel ve Abad-García, 2007, s. 30). Örneğin, Taylor (1968) kullanıcının bilgi gereksiniminin anlaşılması konusuna çok yönlü biçimde yaklaşmıştır. Referans kütüphanecisinin rolüne ve özellikle referans görüşmesinin sofistike/karmaşı niteliğine vurgu yapan yazara göre, referans görüşmesi sürecinde kullanıcının zihnindeki örtük bilgi gereksiniminin varlığı sorun oluşturmaktadır. Bilgiye gereksinimi olan kişinin, zihninde yer alan/zaman zaman da kendisinin de tam olarak tanımlayamadığı o gereksinimi bilmeyen kişiye aktarması kolay değildir. Bu ve benzeri zorluklar nedeniyle referans kütüphanecisinin izleyeceği stratejik yolda, kullanıcının ilgilendiği konuyu, motivasyonunu, kişisel özelliklerini, sorgulama biçimini/tarzını ve beklentilerini kavraması gerekmektedir (Taylor, 1968, s. 178). Yine Taylor'a (1968, s. 179) göre, bilgi gereksinimi olan birey ile bilgi kaynağı arasında iki türlü formun biçimlenmesi söz konusudur. Biri, bireyin bir kişi yani bir referans kütüphanecisi aracılığı/desteği ile çaba göstermesi, diğeri ise bu süreci kendi kendisine yürütmeye 
çalışmasıdır. Kendi kendine yürütülen süreç genellikle başarısızlıkla sonuçlanmaktadır çünkü kullanıcı etkileşime gireceği bilgi sistemi (kütüphane ve içeriği vb.) hakkında genellikle eksik bilgilere sahiptir. Zaman zaman da ya ne istediğinden tam olarak emin değildir ya da alternatif kaynak ve arama yöntemlerinden habersizdir (Taylor, 1968, s. 179).

Nicholas (2000, s. 19), muğlaklığı ve oldukça karmaşık doğası nedeni ile bilgi gereksinimi kavramını tanımlamanın güç olduğuna ve kavramın genellikle istekler (wants) ya da kullanım (use) kavramlarına gönderme yapılırken kullanıldığına işaret etmektedir. Aslında bu her iki kavram da gereksinim kavramının göstergesi olmakla beraber gereksinim kavramını kesin ve tam biçimde nitelememektedir. Yazar, bu bağlamda, pragmatik bir yaklaşımla, yapılması gereken şeyin, insanların bilgi için duydukları gereksinim, bilgiye ulaşmak üzere ifade ettikleri istekler, talepler ve kullanımlara odaklanmak olduğuna inanmaktadır (Nicholas, 2000, s. 19). Genel olarak insan gereksinimleri hakkındaki literatür incelenirse, bilgi gereksiniminin psikologlar tarafından üç kategoride ele alındığı; üç temel insan gereksiniminden birini ve/veya diğerini karşılama arzusu ile ilişkilendirildiği görülür. Bunlardan ilki, fizyolojik gereksinimlerdir (beslenme, barınma vb.). İkincisi, zaman zaman psikolojik veya duygusal gereksinimler olarak da adlandırılan başarma, hâkimiyet kurma gereksinimleri gibi duyuşsal (affective) gereksinimlerdir. Üçüncüsü ise bilişsel gereksinimlerdir (planlama, beceri öğrenme vb.). Şüphesiz bu üç kategori birbirinden bağımsız değildir; aralarında sürekli bir ilişki, bir etkileşim bulunmaktadır. Fizyolojik gereksinimler duyuşsal ve/veya bilişsel gereksinimleri tetikleyebilmektedir; duyuşsal gereksinimler bilişsel gereksinimlere yol açabilmektedir ve bilişsel gereksinimlerin karşılanması ile ilgili problemler (gereksinimlerin karşılanamaması veya gereksinimlerin açıklanması kaygısı gibi) duyuşsal gereksinimlerin (güvence sağlama gibi) ortaya çıkışına neden olabilmektedir. $\mathrm{Bu}$ gereksinimlerin karşılanması arayışı ile birey bilgi arama davranışında bulunabilir. Bilgi gereksinimi, birincil kategoride sınıflandırılmayabilir ancak çağın gittikçe bilgi ile ilişkili/bilgi odaklı yönelimi nedeniyle bilgi eksikliği birey için oldukça ciddi, hatta tehlikeli sonuçlar doğurabilmektedir (Nicholas, 2000, s. 21; Wilson 2006, s. 663).

Nitekim Wilson (2006, s. 663-664), kavrama farklı bir boyut getirmekte ve "bilgi gereksinimi” teriminin profesyonel sözlügüumüzden çıkarılması, onun yerine "gereksinimlerin karşılanmasına yönelik bilgi arayışı" ifadesinin tartışılmasını dahi önermektedir. Ancak bilgi arayanın, aradı ğı yanıtı bulma gereksinimi tek başına belirleyici değildir. Gereksinimler dışında örneğin araştırılanın öğrenilmesinin önemi, tam bilgi edinmeden hareket etmenin karşıllı̆ında ortaya çıkabilecek sonuç ve/veya yaptırımlar, bilgi kaynaklarının mevcudiyeti ve bunları kullanma maliyetleri gibi etkenler de önemlidir. Eksik bilginin tamamlanması ya da inançlar temelinde (önyargılar, inanç ya da ideolojiler, adını ne koyarsak koyalım) birçok karar alınmaktadır. Dolayısıyla, bilgi arama hiç gerçekleşmeyebilmekte ya da gereksinimin tanınması ile arama eylemleri arasında zamanın ertelenmesi söz konusu olabilmektedir. Bunun gibi duyuşsal gereksinimlerin varlığ 1 durumunda, ne gereksinim ne de onun memnuniyetinin eylemci tarafından bilinçli bir şekilde tanınamaması durumu da oluşabilmektedir. Bir diğer olasılık ise, tesadüfen, oldukça düşük bir belirginliğe sahip bilişsel bir gereksinimin, fark edildikten birkaç gün sonra ya da aylar, hatta yıllar sonra giderilebilmesidir. Yine, bireyin herhangi bir bilgi ile karşılaştığında daha önce farkına varmadığı bir bilişsel gereksinimini 
tanıması da olasıdır (Wilson, 2006, s. 664). Anlaşıldı̆̆ı gibi, yazarın irdelediği boyut oldukça karmaşık ve aynı zamanda grift bir yapı taşımaktadır.

Case (2002, s. 5), bilgi gereksinimini, kısaca, kişinin belirlediği herhangi bir hedefe ulaşmak için bilgisinin yetersiz olduğuna ilişkin vardığ farkındalık biçiminde tanımlamaktadır. Choo, Detlor ve Turnbull (2000), bilgi gereksinimini, belirli bir duruma ilişkin deneyim, yaşanılan sorun ya da muğlaklık veya bir şeyden emin olamama süreçlerinde ortaya çıkan durum olarak açıklamaktadır. $\mathrm{Bu}$ durumu tetikleyen pek çok etmen bulunmaktadır. $\mathrm{Bu}$ etmenler, yalnızca üzerinde durulan konunun kendisi ile ilgili olmayabilir. Bunlar, aynı zamanda belirli bir hedef ya da konsensus, bir risk, mesleki ya da sosyal normlar, zaman ve kaynak kısıtlılığı vb. etmenlerle kuşatılmış biçimde, içinde bulunulan duruma göre de değişebilmektedir (Choo, Detlor ve Turnbull, 2000). Kavramsal bağlamda ve kavrama ilişkin etkenler açısından benzer irdelemeler yapan Omiunu (2014, s. 31), bilgi gereksinimi kavramının anlaşılmasında karışıklık olduğu, kavramın yanlış değerlendirildiği görüşündedir. Bilgi gereksinimi üzerine çalışmalar ve modellerde bu kavramın doldurulması gereken bir boşluk (a gap to be filled) biçiminde tanımlandığını ancak bunun eksik bir tanımlama olduğunu düşünmektedir. Bu kavramın eksik ya da yanlış tanımlanması, kendisine göre, bilgi çalışmaları disiplinleri (information studies disciplines) üzerine çalışan bilimciler ve öğrencilerde zihin karışıklığı oluşturmaktadır. Omiunu (2014), fenomenolojik/olgubilimsel çalışmasında bilgi gereksiniminin keşfedilmesi sürecinin, bilinçli ya da bilinçsiz, planlı ya da planlanmamış, sistematik ya da sistematik olmayan, bilimsel ya da bilimsel olmayan bir biçimde gerçekleşebildiğinden söz etmektedir. Dolayısıyla, bilgi gereksinimi, pek çok etmenin (erişilebilen/mevcut bilgi kaynakları; bilginin kullanım alanı, kullanıcının arka planı, motivasyonu, mesleki yönelimi ve diğer bireysel özellikleri, kullanıcıyı çevreleyen sosyal, politik, ekonomik, yasal ve düzenleyici sistemler ve bilgi kullanımının sonuçları vb.) eşlik ettiği karmaşık bir süreç çerçevesinde fark edilen boşluk veya bilgisizliktir. Kruppu (1999, s. 54) ise bilgi gereksinimlerinin -bilginin türü, kapsamı, derinliği- bilgiyi kullanacak kişinin o andaki durumu ve etkinliğine bağlı olarak önemli ölçüde değişkenlik gösterebildiğinden söz eder. Örneğin, yeni bir araştırma alanına giren kişinin bilgi gereksinimleri zaten hâkim olduğu bir konuda belirli bir soruna çözüm arayışını amaçlayan kişinin bilgi gereksinimleri ile aynı değildir.

Bilgi gereksinimi, resmi ya da gayri resmi olanlar da dâhil bilgi kaynakları ve bilgi kanalları ile ilişkili insan davranışının bir bütününü niteleyen bilgi arama davranışının kökünü temsil eder. Dolayısıyla, bilgi gereksinimi ve bilgi arama davranışı birbiriyle iç içe geçmiş, birbirini tamamlayan kavramlardır. Bilgi arama davranışı bilgi gereksinimi sonucunda oluşmaktadır ancak edinilen her bilgi yeni bilgi gereksinimlerini ortaya çıkardığı için bu kavramları birbirinden ayrı ele almak olası değildir (Özenç Uçak, 1997, s. 319; Laltlanmawii ve Verma, 2016, s. 265).

Wilson'un (1997, s. 552-553) aktardığı bilgilere göre, bilgi arama davranış1 probleminin temelinde yer alan en önemli kavram, bilgi gereksinimidir. Kavramı karmaşıklaştıran durum, bilgi gereksiniminin sadece gereksinimi olan kişinin zihninde oluşması; öznel bir deneyim olmasıdır. Bu, gözlemlenemeyen bir durumdur ve yalnızca bilgi davranışının izlenmesi ya da gereksinim sahibinin bunu açıklaması ile anlaşılır (Wilson, 1997, s. 552-553). Sürece eşlik eden bir diğer önemli öge motivasyondur. Hangi nedenle olursa olsun, bir bilgi gereksinimi olan 
kişinin, bu tür davranışlarda bulunmak için onu bu arayışa güdüleyen bir nedeni olduğu varsayılır. Sonuç olarak, Wilson, bilgi arama davranışlarında bireyden ve kaynağın kendisinden kaynaklanan tüm etmenlerin dikkate alınması gerektiği görüşündedir. Bilgi arama davranışlarında üzerinde durulması gereken önemli bağlamlardan birisi özellikle sağlık bilgisi alanında uygulanan stres/başa çıkma kuramının, bu alan (sağlık) dışında uygulanabilirliğinin araştırılmasıdır. Wilson'ın bilgi davranışlarında araştırılmasının önemine inandığı bir diğer konu da risk/ödül modelidir. Burada, bilgi kullanıcıları tarafindan ne tür risklerin algılandığı ve faydalı bilgilerin keşfedilmesinden beklenen kazanımlar (ödül) ile olası riskler arasında nasıl bir dengeleme oluşturulduğu sorgulanmalıdır. Konuya ilişkin bir diğer nokta ise öz-yeterliktir. Kişinin herhangi bir bilgi arama davranışında verimliliğine ilişkin algısının (OPAC: Online Public Access Catalogue - Kamuya Açık Çevrim içi Erişsim Kataloğu kullanımı gibi) doğrudan diğer bilgi arama davranışına (internet arama motoru kullanmak gibi) aktarlabilir olup olmadığı konusu buna bir örnektir. Son olarak, bilgi arama davranışına müdahil olabilecek olası değişkenlerin/engellerin belirli arama durumlarını veya belirli kullanıcı gruplarını nasıl etkilediğiyle ilgili çok fazla araştırmalara gereksinim vardır (Wilson, 1997, s. 570). Anılan tüm bu faktörler (stres/başa çıkma kuramı, risk/ödül modeli ve öz-yeterlik değişkenleri gibi) özellikle cezaevlerinde bulunan bireylerin bilgi davranışları bağlamında, cezaevi ortam ve koşullarının engelleyici, baskılayıcı etkisi nedeni ile özel bir yere sahiptir.

Bilgi davranışı terimi, yalnız bilgi, belge ve kütüphane kullanımıyla ilgili makalelerde kullanılmamış olsa da kökenlerinin kütüphane ve enformasyon bilimi alanı ile ilişkisi açıktır. Chatterjee (2017, s. 4), "bilgi bilimi”" teriminin ilk kez Chris Hanson tarafindan 1956 yllında kullanıldığını ifade eder. (Ancak burada, yazarın aktardığı bilgilere ilişkin dikkati çeken nokta, henüz 1940'larda Birleşik Krallık'ta "meslektaşlarına bilgi bulmak üzere yardımcı olan bilimci" anlamında bilgi bilimci (information scientist) teriminin kullanılıyor olmasıdır). Marco (2012, s. 214) tarafindan verilen bilgilere göre ise İngiltere'de 1958 yllında kütüphane ve bilgi bilimine ilişkin ilk meslek topluluğu olan Bilgi Bilim İnsanları Enstitüsü'nün (Institute of Information Scientists) kurulmasıdır. Bu önemli olayların hepsi birbirine yakın tarihlerde gerçekleşmiştir.

İlerleyen zamanlarda kullanıcı gereksinimleri, bilgi gereksinimleri ve bilgi arama davranışlarına ilişkin pek çok çalışma yapılmış ancak bu çalışmaların en fazla eleştiri alan yönü kuramsal bir gövde ve deneysel bulgulara dayandırılmaması olmuştur (Wilson, 1999, s. 250). 1950'li yıllarda bilgi sistemlerinin geliştirilmesi ve iyileştirilmesi için daha çok bilim insanlarının bilgi sistemlerinden yararlanmalarını ve bilgi sistemlerini kullanmalarını belirlemeye odaklı çalışmalar artış göstermiştir. Daha sonra, bilginin bir sistem tarafından kullanıcıya iletilmesi konusuna odaklanmaktan ziyade kuramlaştırmalara doğru gidilmesi söz konusudur. Zamanla, kullanıcı ile bilgi arasındaki etkileşime koşut biçimde bilgi kuramının üzerinde daha fazla durulmuş ve bilgi davranışı konusunda araştırmaların sayısı artmıştır. 1986'da bilgi bilimi literatürüne ilişkin yapılan incelemelerde bu durum net biçimde gözlenmektedir (Bron, 2013, s. 18). Wilson (1999, s. 250), özellikle İngiltere'de 1970'lerin başlarından itibaren hâkim olan ve daha çok da insan davranışlarının araştırılmasında kullanılan nitel yöntemlerin benimsenmesi geleneğinin, sosyal bilimlerde bilgi davranışı çalışmalarına uygulanabilecek kuram ve modelleri geliştirmeyi tetiklediğini ifade etmektedir. Aynı zamanda, bazı araştırmacılar (örneğin Dervin, Ellis, Kuhlthau, Wilson) tarafindan önerilen modeller ve 
kuramlar, diğer araştırmacılar tarafından daha fazla araştırma yapılmasına temel teşkil ettiği için güç kazanmıştır (Wilson, 1999, s. 250). Bilgi gereksinimleri ve bilgi arama davranış1 terimleri, kullanıcı çalışmaları gibi, bibliyometri, kullanıcı eğitimi vb. çalışmalardan, bilgi erişim tasarımı ve değerlendirmesine kadar çeşitli sorunlu alanlarda kullanılmaktadır. İnsanların bilgiyi nasıl aradıklarını ve kullandıklarını, bilgiye erişebilmek için kullandıkları kanalları ve bilgi kullanımını engelleyen psikolojik, entelektüel, kurumsal, toplumsal vb. engeller veya teşvik edici etmenleri anlamak üzere pek çok disiplin kapsamında çeşitli çalışmalar yapılmaktadır. Bunlar, örneğin, psikolojide kişilik konusu, tüketici davranışlarının incelenmesi, inovasyon çalışmaları, sağlık iletişimi çalışmaları, örgütsel karar verme ve bilgi sistemleri tasarımında bilgi gereklilikleri vb. sorgulamalardır (Wilson, 1994; Wilson, 1997, s. $551)$.

Literatür incelemeleri bilgi davranışları konusunun çok çeşitli kavramlarla ilintili olarak ele alındığını gösterir (Dalkıran, 2019, s. 28):

"Bilgi gereksinimi (information need), bilgi arama (information seeking), bilgi arama süreci (information searching process), bilgi arama davranışı (information seeking behavior), bilgi tarama (information searching), bilgi tarama davranışı (information searching behavior), bilgi toplama (information gathering), bilgi kullanımı (information use), bilgi kullanım davranışı (information use behavior), bilgi paylaşımı (information sharing), bilgi paylaşım davranışı (information sharing behavior), bilgi davranışı (information behavior) ve insanın bilgi davranışı (human information behavior) gibi pek çok kavram kullanılmaktadır."

Bilgi arama davranış1 Ellis'e (2003, s. 300-301) göre, ne tür ve ne amaçla olursa olsun bilgi ararken insanların katıldığı karmaşık eylem ve etkileşim kalıplarıdır. Kavramın tamamlayıcı ifadesi olan "bilgi gereksinimi" gibi, bu ifadenin irdelenişinde de, açıklayıcı içeriğinden ziyade yararlılığı üzerinde durulmaktadır. Kavram, bilginin arandığı tüm bağlamları ve tüm bilgi arama biçimlerini kapsamaktadır (Ellis, 2003, s. 300). İnsanın, kişisel ve toplumsal gelişimini sağlaması, yaşamını sürdürebilmesi, ilişkilerini düzenleyebilmesi için bilgiye gereksinimi bulunmaktadır. Çeşitli etkenlere bağlı biçimde ortaya çıkan bilgi gereksinimi ile oluşan bilgi arama davranışı yine çeşitli etmenler nedeni ile her insanda farklı olarak biçimlenmektedir. Bilgi gereksinimi, kişinin içinde bulunduğu belirsiz ya da şüpheli durumu mevcut bilgileri ile aşamaması durumunda ortaya çıkmaktadır (Özenç Uçak, 1997, s. 315-317).

Spink’e göre (2010), bilgi davranışı, öğretilmeyen, doğuştan kazanılmış bir bilişsel yetenektir. Birey, doğuştan gelen bu yetisi ile çevresini anlamlandırmak için bilgiyi bulma, düzenleme ve kullanma davranışlarına girişir. Spink, bilgi davranışı konusunun genellikle çağdaş kaygı ve pragmatik yaklaşımla ele alındığı; köklerine yeterince inilmediği görüşündedir. Kendisine göre, konuya daha geniş perspektiften ve bütünsel yaklaşmak, bunun için de mutlaka ilişkili tüm disiplinlerden yararlanmak gerekir. Konu bağlamında, biyoloji, evrim, bilişim, antropoloji, bilişsel arkeoloji, psikoloji gibi bilimlerde geliştirilmiş kuram ve modeller önemli dayanaklardır. Spink, bilgi davranışının içgüdüsel, sosyo-bilişsel bir beceri olduğunu ve ancak çok disiplinli bir vizyon ile araştırıldığı zaman anlaşılabileceğini ileri sürmektedir. Spink, aynı zamanda, bilgi davranışında cinsiyet ve benzeri değişkenler de dâhil duygusal durumlara etki eden bireysel farklılıklar ile kişilik özelliklerinin önemine de vurgu yapar (Spink, 2010; Demir, 2015b). 


\section{Literatür Değerlendirmesi: Mahkûmların Bilgi Gereksinimi ve Bilgi Davranışı}

Uluslararası literatüre dayanan ve mahkûmların bilgi gereksinimi, bilgi davranışı ve bu bağlamdaki etmenlere ilişkin araştırmalar pek çok ülkede cezaevlerinde bulunan mahkûmların genellikle okuryazarlık düzeyi ve eğitim altyapılarının zayıf olduğunu ortaya koymaktadır (Wilhelmus, 1999; Ljodal ve Ra, 2011, s. 484; Gabhann, 2013, s. 19; Mortensen, 2015, s. 2; Eze, 2016, s. 247; Garner, 2017a, s. 335-336; Garner, 2017b, s.19, 183; Biju ve Johnson, 2018, s. 73; Sambo ve Ojei, 2018, s. 8; Umamaheswar, 2018; McInerney, 2019, s. 21). Ayrica, Tarzaan, Chorun ve Mbatsoron (2015, s. 194) eğitim ile tekrar suç işleme arasında anlamlı bir korelasyon olduğunu, eğitimin suç işleme eğilimini azalttığını ifade etmiş ve bu bağlamda kütüphanelerin rolünün de önemli olduğuna işaret etmiştir. Bu nedenlerle bilgi gereksinimi ve davranışlarını önemli düzeyde etkilediği düşünülen eğitim faktörü önemle ele alınmalıdır.

Nitekim okuryazarlık eğitimi de dahil eğitim (Visher ve Lattimore, 2007, s. 31; Bajić, 2015, s. 525; Omolola, 2015, s. 72; Tarzaan ve diğerleri, 2015, s.196; Emasealu ve Popoola, 2016, s. 10; Scott, 2016, s. 34-38; Sambo, Usman ve Rabiu, 2017, s. 1-2; Emasealu, 2018, s. 40-42; Ijiekhuamhen ve Aiyebelehin, 2018, s. 108; Sambo ve Ojei, 2018, s. 9; Chandani, 2019b, s. 153; Usman, Istifanus ve Audu, 2019, s. 70-72; Rafedzi, Abrizah ve Yu, 2016; Rafedzi, Zainal, Yu ve Kamal, 2018; Canning ve Buchanan, 2019, s. 421-422) ve mesleki eğitim çok fazla talep edilen bilgiler arasındadır (Tarzaan ve diğerleri, 2015, s. 196; Scott, 2016, s.34-38; Emasealu, 2018, s. 40-42; Chandani, 2019b, s. 153).

Bunun dışında, mahkûmların bilgi gereksinimlerinin ağırlıklı olarak tıbbi destek ve sağlık (Bajić, 2015, s. 525; Drabinski ve Rabina, 2015, s. 45; Tarzaan ve diğerleri, 2015, s. 196; Emasealu ve Popoola, 2016, s. 10; (Eze, 2016, s. 246; Scott, 2016, s. 34-38; Sambo ve diğerleri, 2017, s. 1-2; Emasealu, 2018, s. 42; Ijiekhuamhen ve Aiyebelehin, 2018, s. 108; Sambo ve Ojei, 2018, s. 9; Chandani, 2019b, s. 152; Usman ve diğerleri, 2019, s. 70) ile mahkûmların davalarına ilişkin mevzuat desteği ve diğer hukuk konuları olduğu görülmektedir (Bajić, 2015 s. 525; Drabinski ve Rabina, 2015, s. 45; Omolola, 2015, s. 72; Tarzaan ve diğerleri, 2015, s. 196; Emasealu ve Popoola, 2016, s. 10; Eze, 2016, s. 247; Scott, 2016, s. 34-38; Sambo ve diğerleri, 2017, s. 1-2; Canning ve Buchanan, 2019, s. 421-422; Emasealu, 2018, s. 42; Sambo ve Ojei, 2018, s. 9; Chandani, 2019b, s. 152).

Gereksinim duyulan diğer bilgiler arasında finansal konular (Bajić, 2015, s. 525; Emasealu ve Popoola, 2016, s. 10; Eze, 2016, s. 246; Scott, 2016, s. 34-38; Sambo ve diğerleri, 2017, s. 1-2; Emasealu, 2018, s. 42; Ijiekhuamhen ve Aiyebelehin, 2018, s. 108; Sambo ve Ojei, 2018, s. 9; Chandani, 2019b, s. 152), cezaevi kuralları ve mahkûm hakları yer almaktadır (Bajić, 2015, s. 525; Scott, 2016, s. 34-38; Sambo ve diğerleri, 2017, s 1-2; Canning ve Buchanan, 2019, s. 421-422; Ijiekhuamhen ve Aiyebelehin, 2018, s. 108; Sambo ve Ojei, 2018, s. 9).

Kültürel olay ve etkinlikler (Bajić, 2015, s. 525), kişisel gelişim ve ahlak (Drabinski ve Rabina, 2015, s. 47; Emasealu ve Popoola, 2016, s. 10; Sambo ve diğerleri, 2017, s. 1-2; Emasealu, 2018, s. 40-42; Ijiekhuamhen ve Aiyebelehin, 2018, s. 108; Sambo ve Ojei, 2018, s. 9), dini bilgiler ve destek (Bajić, 2015, s. 525; Tarzaan ve diğerleri, 2015, s. 196; Eze, 2016, s. 247; Chandani, 2019b, s. 152; Usman ve diğerleri, 2019, s. 70-72), aile, arkadaş ve yakınlarla ilgili bilgiler (Bajić, 2015, s. 525; Sambo ve diğerleri, 2017, s. 1-2; Sambo ve Ojei, 2018, s. 9), çeşitli pratik bilgi ve beceriler (Omolola, 2015, s. 72; Emasealu ve Popoola, 2016, s. 10; Eze, 2016, s. 246; Emasealu, 2018, s. 40-42; Ijiekhuamhen ve Aiyebelehin, 2018, s. 108; Sambo ve 
Ojei, 2018, s. 9; Usman ve diğerleri, 2019, s. 70-72), güncel haber ve olaylar (Visher ve Lattimore, 2007, s. 31; Bajić, 2015, s. 525; Drabinski ve Rabina, 2015, s. 47; Eze, 2016, s. 246; Emasealu, 2018, s. 40-42; Ijiekhuamhen ve Aiyebelehin, 2018, s. 108; Chandani, 2019b, s. 153) yoğun olarak gereksinim duyulan diğer konulardır.

Bunların dışında en çok gereksinim duyulan bilgiler, cezaevi sonrası serbestlikle beraber iş bulma, konaklama, finans vb. konulardır (Visher ve Lattimore, 2007, s. 31; Bajić, 2015, s. 525; Drabinski ve Rabina, 2015, s. 47; Scott, 2016, ss.34-38; Sambo ve diğerleri, 2017, s. 1-2; Canning ve Buchanan, 2019, s. 421-422; Emasealu, 2018, s. 40-42; Ijiekhuamhen ve Aiyebelehin, 2018, s. 108; Sambo ve Ojei, 2018, s. 9). Eğlence ve dinlenmeye ilişkin materyal ve araçlar da mahkûmlar tarafından çok fazla talep edilmektedir (Omolola, 2015, s. 72; Tarzaan ve diğerleri, Chorun ve Mbatsoron, 2015, s. 196; Emasealu ve Popoola, 2016, s. 10; Eze, 2016, s. 246; Rafedzi ve diğerleri, 2016, s. 102; Usman ve diğerleri, 2019; s. 70-72).

Uluslararası literatüre göre en fazla başvurulan bilgi kaynakları sorgulandığında ise televizyonun üst sıralarda yer aldığı ortaya çıkmıştır (Tarzaan ve diğerleri, 2015, s.196; Scott, 2016, s. 38-45; Ijiekhuamhen ve Aiyebelehin, 2018, s. 109; Sambo ve Ojei, 2018, s. 10; Usman ve diğerleri, 2019, s. 70-72. Yine üst sıralarda bulunan diğer kaynaklar aile, arkadaş ve yakınlardır (Bajić, 2015, s. 525; Scott, 2016, s. 38-45; Sambo ve diğerleri, 2017, s. 1-2; Ijiekhuamhen ve Aiyebelehin, 2018, s. 109; Sambo ve Ojei, 2018, s. 10; Usman ve diğerleri, 2019, s. 70-72).

Bunun yanında öğretmenler (Scott, 2016, s. 38-45) ve cezaevi görevlileri de mahkûmların en fazla tercih ettiği bilgi kaynaklarıdır (Bajić, 2015, s. 525; Tarzaan ve diğerleri, 2015, s.196; Scott, 2016, s. 38-45; Canning ve Buchanan, 2019, s. 421-422; Ijiekhuamhen ve Aiyebelehin, 2018, s. 109; Sambo ve Ojei, 2018, s. 10; Usman ve diğerleri, 2019, s. 70-72).

Başvurulan diğer bilgi kaynakları, diğer mahkûmlar (Bajić, 2015, s. 525; Scott, 2016, s. 38-45; Canning ve Buchanan, 2019, s. 421-422), avukat vb. yasal mekanizmalar (Bajić, 2015, s. 525; Tarzaan ve diğerleri, 2015, s.196; Ijiekhuamhen ve Aiyebelehin, 2018, s. 109; Sambo ve Ojei, 2018, s. 10), kilise, cami vb. dini mekanizmalar (Eze, 2016, s. 251; Scott, 2016, s. 3845; Sambo, Usman ve Rabiu, 2017, s. 1-2; Canning ve Buchanan, 2019, s. 421-422; Ijiekhuamhen ve Aiyebelehin, 2018, s. 109; Sambo ve Ojei, 2018, s. 10; Usman ve diğerleri, 2019, s. 70-72) ve sağlık görevlileridir (Tarzaan ve diğerleri, 2015, s.196; Scott, 2016, s. 3845; Sambo, Usman ve Rabiu, 2017, s. 1-2; Ijiekhuamhen ve Aiyebelehin, 2018, s. 109).

Mahkûmların en az tercih ettikleri bilgi kaynakları ise sosyal hizmet görevlileri (Eze, 2016, s. 251; Scott, 2016, s. 38-45); duyuru panoları ve posterler (Tarzaan, Chorun ve Mbatsoron, 2015, s.196; Scott, 2016, s. 38-45; Canning ve Buchanan, 2019, s. 421-422; Sambo ve Ojei, 2018, s. 10) ile kütüphanedir (Bajić, 2015, s. 525; Scott, 2016, s. 38-45; Sambo ve diğerleri, 2017, s. 1-2; Canning ve Buchanan, 2019, s. 421-422; Ijiekhuamhen ve Aiyebelehin, 2018, s. 109; Sambo ve Ojei, 2018, s. 10).

Uluslararası literatüre göre, bilgi gereksinimi ile bilgi davranışlarını olumsuz biçimde etkileyen etmenler, düşük okuryazarlık ve eğitim (Bouazza, 1989, s. 155-159; Campbell, 2005, s. 18; Visher ve Lattimore, 2007, s. 31; Bajić, 2015, s. 525; Omolola, 2015, s. 72; Tarzaan ve diğerleri, 2015, s. 196; Emasealu ve Popoola, 2016, s. 10; Rafedzi ve diğerleri, 2016; s. $102-$ 107; Scott, 2016, s. 34-38; Sambo ve diğerleri, 2017, s. 1-2; Canning ve Buchanan, 2019, s. 421-422; Emasealu, 2018, s. 40-42; Ijiekhuamhen ve Aiyebelehin, 2018, s. 108; Sambo ve Ojei, 
2018, s. 9; Chandani, 2019b, s. 153; Usman ve diğerleri, 2019, s. 70-72) ve diğer demografik, kişisel özellikler, inançlar, sosyoekonomik ve kültürel durumlardır (Bouazza, 1989; s. 155-159; Reading, 2011, s. 127; Agarwal, 2018, s. 62).

Mahkûmların bilgi gereksinimi ve davranışlarını en fazla engelleyici diğer etmenler arasında cezaevlerinin baskı oluşturan doğası ve sınırlar oluşturan politikaları ile görevlilerin olumsuz tutumu vb. etmenler anılmaktadır (Eze, 2015, s. 285-298; Eze, 2016, s. 248; Scott, 2016, s. 38-45; Sambo ve diğerleri, 2017, s. 1-2; Emasealu, 2018, s. 43; Ijiekhuamhen ve Aiyebelehin, 2018, s. 111; Chandani, 2019a, s. 72; Chandani, 2019b, s. 153; Bingman-Forshey ve Gibbons, 2020, s. 68). İnternet erişiminin engellenmesi çok fazla vurgulanan diğer önemli bir sorundur (Wilhelmus, 1999, s. 117; Bajić, 2015, s. 526; Drabinski ve Rabina, 2015, s. 45; Emasealu ve Popoola, 2016, s. 11; Scott, 2016, s. 46- 51; Ijiekhuamhen ve Aiyebelehin, 2018, s. 109-110; Bingman-Forshey ve Gibbons, 2020, s. 68). Benzeri biçimde, sorunlar arasında sansür de çok sık ele alınmaktadır (Wilhelmus, 1999, s. 117; Eze, 2015, s. 285-298; Emasealu, 2018, s. 44; Chandani, 2019b, s. 153; Bingman-Forshey ve Gibbons, 2020, s. 68). Dil sorunu literatürde anılan diğer bir engelleyici etmendir (Campbell, 2005, s. 23; Tarzaan ve diğerleri, 2015, s. 196-197; Emasealu, 2018, s. 40-42).

Yoğun olarak irdelenen diğer sorunlar cezaevlerinin ve cezaevi kütüphanelerinin bütçe sıkıntısı (Eze, 2015, s. 285-298; Sambo ve diğerleri, 2017, s. 1-2; Ijiekhuamhen ve Aiyebelehin, 2018, s. 109; Sambo ve Ojei, 2018, s. 10; Chandani, 2019a, s. 72) ve dolayisiyla cezaevlerinde bilgi kaynaklarının erişilebilirliği, kütüphanelerin güncel yayından yoksunluğu vb. sorunlardır (Bouazza, 1989; Drabinski ve Rabina, 2015, s. 47; Eze, 2015, s. 285-298; Tarzaan ve diğerleri, 2015, s. 196-197; Emasealu ve Popoola, 2016, s. 12; Eze, 2016, s. 248; Rafedzi ve diğerleri, 2016, s. 102-107; Sambo ve diğerleri, 2017, s. 1-2; Emasealu, 2018, s. 40-42; Ijiekhuamhen ve Aiyebelehin, 2018, s. 109; Sambo ve Ojei, 2018, s. 10; Rafedzi ve diğerleri 2018, s. 87; Chandani, 2019a, s. 72; Chandani, 2019b, s. 152-153; McInerney, 2019, s. 22).

Mahkûmların bilişsel ve ruhsal durumu üzerinde önemli oranda belirleyici olan ve başlı başına bir araştırma konusu olabilecek etmenlerden biri de cezaevi kültürüdür. Cezaevi kültürünün etken olduğu grup aidiyeti, grup odaklı bilgi arama davranış biçimleri, muhbir olarak etiketlenme kaygısı, cezaevi görevlileri ile mahkûmlar ve mahkûmlarla mahkûmlar arasında güvensizlik, can güvenliği vb. korkular (Campbell, 2005, s. 30; Scott, 2016, s. 46- 51) mahkûmların bilgi gereksinim ve davranışlarında özel bir boyut oluşturmaktadır. Anılan etmenlerle beraber mahkûmlara karşı önyargı oluşturulması ve etiketlenme, onlarda özgüven ve özsaygı sorununu da ortaya çıkarmaktadır. Canning ve Buchanan (2019, s. 430-431) mahkûmların bilgi davranışlarına en fazla etki eden etmenlerin özgüven ve diğerlerine güven sorunu ile yanlış bilgilendirme, dezenformasyon ve pratik erişim sorunları olduğunu belirtmektedir. Mahkûmlar, bilgi arama davranışlarında diğerlerinden yardım istemekten çekinmekte, kendilerini yük olarak görmektedirler. Ayrıca mahkûmların hem cezaevi personeli hem de diğer mahkûmlarla bilgi paylaşmak konusunda güven sorunları da öne çıkmaktadır. Mahkûmlar, bu ortamda kime güveneceklerini bilmediklerinden yakınmaktadır. Aşağılanma ve/veya şiddet görme korkusu, bilgi paylaşımını engelleyen önemli bir etmendir.

Yerli literatürde Türkiye'deki hükümlü ve tutukluların bilgi gereksinimleri ile bilgi davranışlarını sorgulayan herhangi bir çalışmaya rastlanmaması önemli bir boşluğu 
göstermektedir. Bununla beraber, sınırlı sayıda da olsa cezaevi kütüphanelerinin durumunu ve sorunlarını sorgulayan kaynaklar bulunmaktadır. Okuryazarlık ile çeşitli bilgi ve becerilerin geliştirilmesine ve sosyalleşmeye katkısı göz önüne alındığında, nitelikli cezaevi kütüphaneleri, bilgi ve bilgi kaynakları erişimi sınırlı ve sosyal yaşamdan uzak kalan mahkûmlar için tartışılmaz öneme sahiptirler.

Kronolojik sırası ile irdelenirse, Kongar'ın (1982) Türk Ceza ve Infaz Kurumlarında Kültür ve Eğitim adlı makalesinde cezaevlerinin daha iyi duruma getirilmesinde eğitsel ve kültürel bağlamda neler yapılması gerektiği tartışılırken bu kurumlarda kütüphane kurmanın önemine dikkat çekilmiştir. Önal'ın (1984) Cezaevlerine Halk Kütüphanesi Hizmetleri adlı çalışması oldukça önemli sorunlara işaret etmesi bağlamında dikkati çeken bir çalışmadır. Önal (1984, s. 129), makalesinde Türkiye'de T.C. Kültür ve Turizm Bakanlığı ile T.C. Adalet Bakanlığının yayımladığı yönetmelik ve genelgelerle cezaevlerine halk kütüphanesi hizmetlerinin verilmesinin talep edildiğine değinmektedir. Ancak ülke genelinde cezaevlerine halk kütüphaneleri tarafından yeterli düzeyde hizmet götürülmediği, bu uygulamaların kişiler arası ilişkilerle sınırlı kaldığını da ekleyerek temel bir sorunu gündeme taşımıştır. Söz konusu çalışma, cezaevi kütüphaneleri için nitelikli insan gücü ve bütçe sağlanması vb. önerileri ile konuya ilişkin önemli bilgileri içeren, oldukça değerli ve yönlendirici bir çalışmadır. Bir diğer önemli ve değerli çalışma ise Öner'in (2003) ceza infaz kurumları ile ilgili bir sempozyumda sunduğu Türkiye'de Hapishane Kütüphaneleri başlıklı bildiridir. Öner (2003), mahkûmların topluma yararlı kişiler olarak dönmesinde cezaevi kütüphanelerinin rolüne ve halk kütüphaneleriyle ilişkilerinin yararına işaret etmektedir. Hem Önal (1984) hem de Öner (2003) özellikle cezaevi kütüphanelerinde nitelikli kütüphanecilerin işlevlerinin altını çizmektedir.

Türkiye'deki cezaevi kütüphanelerinin durumu ve sorunlarına ilişkin yerli literatürde bulunan diğer bir çalışma Demir (2015a) tarafından hazırlanan Ceza Infaz Kurumu Kütüphaneleri ve Türkiye'de Durum başlıklı çalışmadır. Bu çalışma Demir'in (2011) Ceza Infaz Kurumu Kütüphaneleri: Dünyada ve Türkiye'de Durum başlıklı doktora tezine dayanarak genişletilmiş bir çalışmadır.

Demir'in (2015a) çalışması kapsamında, 137 cezaevinde uygulanan bir anket araştırması (Demir, 2011) ile elde edilen bulguların değerlendirilmesi sonucunda cezaevlerinin halk kütüphaneleri tarafindan desteklenmesi talebine ilişkin mevzuata karşın bu desteğin yeterli oranda sağlanmadığı sonucuna varılmıştır. Cezaevi kütüphanelerinin bütçe, güncel kaynak ve mekân yetersizliği olması, hizmetlerin kütüphaneciler yerine cezaevi öğretmenleri veya infaz koruma memurları (zaman zaman da iyi halli mahkûmlar) tarafından yürütülmesi gibi durumlar ivedilikle çözüm bulunması gereken sorunlardır.

Yerli literatürde konuya ilişkin bir diğer kaynak ise Koç (2018) tarafından hazırlanan Cezaevi Kütüphaneleri: Kırşehir Açık Ceza İnfaz Kurumu Kütüphanesi Örneği adlı çalışmadır. $\mathrm{Bu}$ çalışmada genel olarak bireyin entelektüel ve mesleki gelişimi, eğitimi vb. konularda desteği ile cezaevi kütüphanelerinin önemine değinilmekte ve Kırşehir Açık Ceza İnfaz Kurumunun bu bağlamda durumu irdelenmektedir. Kütüphane dermesinin felsefe, sosyal bilimler ve fen bilimleri ile ansiklopedilerden ve çeşitli hikâye ile edebi eserlerden oluştuğu ve sürekli güncellendiği belirtilmektedir. Ayrıca kurum kütüphanesine yeni ve güncel kitaplar kazandırmak amacıyla bağış kampanyalarının düzenlendiği ve kütüphanenin Kırşehir İl Halk Kütüphanesi ile iş birliği yaparak ödünç kitaplar sağladığı da vurgulanmaktadır. Ek olarak 
Kırşehir Halk Kütüphanesinin belirli dönemlerde hükümlü/tutukluların kullanımı için koleksiyon paylaşımı yaptığı bilgisi de yer almaktadır (Koç, 2018, s. 804). Anılan çalışmada herhangi bir soruna değinilmemesi örnek alınan kütüphanenin durumunun yazar tarafından yeterli görüldüğü izlenimini vermektedir.

Türkiye'de cezaevi kütüphanelerinin durumu, mahkûmların bilgi gereksinimleri vb. konularda kaynakların kısıtlılı̆̆ına karşın özellikle son yıllarda medyada çıkan bazı haberler mikro düzeyde olsa dahi konuya ilişkin farkındalığın varlığına ve birtakım gelişmelere işaret etmektedir. Adıyaman İl Halk Kütüphanesi Müdürü Filiz Karabulut tarafindan Adıyaman E Tipi Kapalı Ceza İnfaz Kurumunda mahkûmlar için organize edilen ve kütüphanelerin önemine değinilen seminer (Karaca, 2015) bunun bir örneğidir. Yine, Mardin E Tipi Cezaevinde bulunan kütüphaneye baro tarafından 500 kitap bağışının yapılması ve Mardin Cumhuriyet Başsavcısı Ahmet Bektaş'ın önerdiği en yoğun kitap okuyana ödüller verilmesi (eşlerle daha fazla görüşmek gibi) uygulaması (Ordu, 2019); Kayseri Kadın Kapalı Ceza İnfaz Kurumunda bağışçı ve sponsorlar desteği ile 4 bin 700 kitabın yer aldığı okuma salonları ile bir kütüphanenin kurulması ve kütüphanede okuma salonlarının yanı sıra cezaevinde yaşayan mahkûm çocuklarının vakit geçirebileceği alanların oluşturulması (Anadolu Ajansı, 2019) gibi haberler umut vericidir. Gazeteci yazar Çölaşan'a (Ayhan, 2019) mahkûmlardan gelen mektuplarda dile getirilen kitap talepleri ile cezaevlerinde başlatılan kitap seferberliği de bu gelişmelerden bir diğeridir. $\mathrm{Bu}$ talepler Adalet Bakanlığı tarafından kabul görmüş ve Kültür ve Turizm Bakanlığına bağlı kütüphanelerde bulunan 16 milyon kitabın ödünç olarak cezaevlerine gönderilmesi kararlaştırılmıştır. Ayrıca cezaevlerine belli günlerde kabul edilen kitaplar için de esneklik sağlanmış ve dini bayramlar, yılbaşı ve mahkûmun doğum günü dışında gönderilen kitapların da kabul edilmesi uygun görülmüştür (Ayhan, 2019).

Çölaşan'a yazılan söz konusu mektuplar arasında Bayburt Cezaevinden yazan mahkûm Çağatay Kızıltaş’ın ifadesi mahkûmlar için kitabın ne oranda önemli olduğuna dair çok anlamlı bir mesajı içermektedir: "Burasını güzelleştiren iki şey var. Biri aile görüşü, diğeri kitap..." (Çölaşan, 2019). Kitap ve kütüphane, cezaevinde sınırlılıklar ve kurallarla kuşatılan mahkûm için dış dünya ile kuracağı en önemli bağlantılardan biridir. Bu temel farkındalık dahi tek başına pek çok sorunun çözümüne 1ş1k tutacaktır.

\section{Mahkûmların Bilgi Gereksinimi ve Bilgi Davranışına İlişkin Genel Bir Değerlendirme}

Fiziksel, zihinsel, sosyal, toplumsal durumları/sorunları nedeniyle, diğer vatandaşlarla eşit ya da benzer biçimde eğitim vb. olanaklar ve topluma katılım haklarına sahip olmayan kişiler "dezavantajlı" biçiminde nitelenirler. Dezavantajlı terimi, ırk, cinsiyet, etnisite, ekonomik durum, dil, coğrafi konum, çevre, eğitim ve engellilik nedenleriyle belirli bir toplumda düşük statüye sahip bireyler veya gruplar için kullanılmaktadır (Butdisuwan, 1999). IFLA'nın özel bir topluluğunun (IFLA LSDP= Section of Libraries Serving Disadvantaged Persons) ilgi odağ olan bu grup içerisinde hastanelerde bulunan hastalar, huzurevleri ve özel bakım tesislerindeki yaşlılar, çeşitli nedenlerle evden çıkamayanlar, sağırlar, fiziksel, gelişimsel veya öğrenme güçlüğü çekenler ile beraber mahkûmlar da yer almaktadır (Lithgow, 1999).

İnsanlık tarihi boyunca suç işleyene karşı yöneltilen anlayış, onu düşman ilan etme, toplumdan dişlama, zindana atma ve benzeri biçimlerde olmuştur. Söz konusu bu anlayıştan günümüzün modern anlayışına ulaşılması oldukça zorlu uğraşları içeren bir tarihçeye sahiptir. 
Günümüzde ulaşılan noktada dahi söz konusu kurumların tam anlamıyla insan hakları ve onurunu koruyan, hükümlü ya da tutukluya işlediği suç her ne olursa olsun bir "birey" gibi davranmayı esas alan yapıya kavuşamadığı düşünülmektedir (Demir, 2015a, s. 7). Öte yandan, sosyolojik bağlamda toplumların mahkûmları dışlayan tutumu, günümüzde dahi var olan bir durumdur. Nitekim Campbell (2005, s. 18), mahkûmları, bizlerden farklı kişiler gibi algıladığımızdan ancak biz veya ailemizden birinin cezaevine girmesi durumunda bu algımızın değiştiğinden söz etmektedir. Ceza sistemleri birçok ülkede iyi davranışları yaymak ve birlikte yaşayan kişilerin yasaları yıkmasına engel olmak amacı ile uygulanmaktadır. Bunun için suçlunun rehabilite edilmesi ve cezaevleri ile toplum kuruluşları arasında köprü oluşturmak gerekmektedir (Önal, 1984, s. 120). Bireyin cezaevine adaptasyonu hemen her zaman sorunlara yol açan ve cezaevi sonrası yaşamında da olumsuz yansımalar oluşturabilen bir durumdur. Genel olarak hapsedilen pek az kişinin hiçbir biçimde incinmemiş ya da değişime uğramamış olduğu söylenebilir. Kısacası, cezaevi ortam ve koşulları, genel olarak olumsuz etkilere sahiptir; hapsedilmiş kişiler çoğu zaman, (mahremiyeti aşan ölçülerde) diğerleri ile yaşama ve etkileşime girmenin getirdiği acı, yoksunluk ve alışılmamış norm ile kalıpların yarattığı atmosfere maruz kalmaktadır. Cezaevlerinde mahkûmlar için uygulanan birçok rehabilitasyon ve benzeri program ise tek başına mahkûmlara cezaevi sonrası hak ettikleri anlamlı, tatmin edici yaşamı sürdürmelerine olanak sağlayacak yeterlilikte olmadığından, gerçekçi de değildir. Cezaevlerinden çıkan mahkûmların büyük çoğunluğu geri döndükleri yaşamı ve toplulukları anlamlandırmakta, onlara uyum sağlamakta güçlük çekmektedir. Bunların dışında, girdikleri hemen her geleneksel ortamda onları dışlayan mahkûm damgası da onlar için başlı başına bir yüktür (Haney, 2002, s. 79; Haney, 2012, s. 17). Mahkûmlar, cezaevlerinin geri döndükleri topluma yeniden entegre olmalarını engelleyebilecek ve onları gelecekteki kişisel, sosyal ve işle ilgili etkileşimlerde işlevsel olarak devre dışı bırakabilecek kalıcı etkileriyle mücadele etmektedir. En önemlisi de, daha önce de vurgulandığı gibi, onlar cezaevinde kaldıkları sürede, teknolojik, mesleki, sosyal ve hatta özel yaşamları bağlamında, onlarsız gelişen, değişen, dönüşen bir dünya ile karşı karşıyadırlar. Bu nedenlerle, cezaevindeki bireylere sunulacak kapsamlı ve yeterli nitelikte destek, hizmet, olanak, program ve uygulamalar, onların yalnız cezaevi sürecindeki yaşamlarında değil aynı zamanda sonraki yaşamlarında da başarı ve huzurlarını sağlamayı kolaylaştıracaktır (Haney, 2012, s. 17).

Cezaevinde bulunan (tutuklu ya da hükümlü) bireylerin, pek çok hak gibi, eğitim ve öğrenim hakları vardır. Bu haklar, uluslararası sözleşme ve düzenlemeler ile de garantiye alınmaktadır ${ }^{1}$. Birçok mahkûm için, bu eğitim ve öğretim hakkını kullanmak, yaşamlarında yeni bir sayfa açabilmek anlamında onlara katkı sunar. Mahkûmlara eğitim olanakları sağlamak yalnız yasal bir zorunluluk olarak dikkate alınmamalıdır. Hümanist bağlamda, cezaevindeki

\footnotetext{
${ }^{1} 1948$ tarihli Insan Haklarl Evrensel Bildirgesi'nin 26. Maddesi ve 1966 tarihli Ekonomik, Sosyal ve Kültürel Haklar Uluslararası Sözleşmesi'nin 13. Maddesi herkesin, eğitim hakkına sahip olduğu ve bu hakkın devletler tarafından korunması gerektiğine işaret eder. Ayrıca, 1977 tarihli Mahpusların Islahı İçin Asgari Standart. Kurallar kapsamında yer alan 77. Madde "bütün mahpuslara kendilerine yarar sağlayacak öğretim ile dinsel eğitimin verilmesi mümkün olan ülkelerde dinsel eğitim" verilmesine dikkati çekmekte ve aynı madde kapsamında "okur-yazar olmayan mahpuslar ile genç mahpusların eğitimi zorunludur" denilerek verilecek eğitimin mümkün olduğu takdirde, ülkenin eğitim sistemi ile bütünleştirilmesi gerektiği ifade edilmektedir. 1955 'de yayınlanan ve 2015 'de yeniden gözden geçirilen "Mahpuslara Muameleye Dair Birleşmiş Milletler Asgari Standart Kuralları"nın 98.maddesinde de "mahpusun salıverildikten sonra dürüst bir şekilde yaşama yeteneğini sürdürecek ya da artıracak tarzda" çalışmaların gerçekleştirilmesi ve bu çerçevede "mahpuslara ve özellikle genç mahpuslara kazanç elde edebilmeleri için, yararlı işkollarında meslek eğitimi” sağlanmasına vurgu yapılmıştır.
} 
bireylerin eğitimi de dâhil olmak üzere, eğitim, medeni toplumun önemli bir özelliğidir. Eğitim, doğası gereği çok çeşitli bilgi ve becerilerin kazanılmasında değerli bir faktördür; insanın gelişimine katkıda bulunur (Eikeland, Manger ve Asbjørnsen, 2009, s. 17). Eğitim alt yapısının güçlü olması, mahkûmun bilgi arayışında da farklılık yaratmaktadır.

Campbell (2005, s. 19), literatürde, bilgi bilimi ve benzeri çalışmalarda her ne kadar cezaevi nüfusu görmezden gelinmese de kullanıcı odaklı ve gözleme dayanan çalışmaların sınırlı oluşuna dikkati çekmektedir. Kendisine göre, bu bağlamda, diğer disiplinlerin desteği ile Wilson'ın Bilgi Davranışı Modelini uygulayarak mahkûm bilgi davranışının daha net ve daha derin bir şekilde anlaşılması mümkündür. Büyük olasılıkla, Wilson'ın geliştirdiği modelin mahkûm bilgi davranışları üzerinde uygulanabilirliğine ilişkin en somut gerekçe, 1981 yılında oluşturduğu modelde eksik bulduğu ve 1996 'da tamamladığı özelliklerdir. Wilson ilk modelinde (1981), bireyin elde ettiği bilgi ile tatmin olup olmadığı üzerine odaklanmıştır. Ancak, daha sonra, bireyin içinde bulunduğu koşullar ile bilgi ararken karşılaştığı engelleri ve elde edilen bilgiyle etkileşimini yansıtmaması nedeniyle bu modelini eksik bularak geliştirmiştir (Yıldız ve Özenç Uçak, 2014, s. 5). Şüphesiz, cezaevinin kendine özgü koşullarının birey üzerindeki etkisi, onun bilgi arama davranışlarını da etkileyecektir. Campbell (2005, s. 19) tarafindan konu ile doğrudan ilişkilendirilmesi nedeni ile Wilson'un geliştirdiği modelin anılan bağlamı ile biraz daha ayrıntılı biçimde açıklanmasında yarar vardır:

Wilson 1981 yılında geliştirdiği modelde, bilgi davranışının bir bilgi kullanıcısı tarafından hissedilen bilgi gereksinimlerinin, farklı aşamalarda veya farklı öncelikler ile algılanması nedeniyle ortaya çıktığını ileri sürmektedir. Bu gereksinimini karşılamak için, kullanıcı resmi veya gayrı resmi bilgi kaynakları veya hizmetleri talep eder. Resmi kaynaklar, kütüphaneler ya da çevrim içi kaynaklar olabilir. Bunun dışında, diğer kişilere başvurarak bilgi paylaşımı yapılabilir. $\mathrm{Bu}$, modelin iletişim boyutunu sergileyen yönü, bilgi transferi (information transfer) ile beraber bilgi alışverişi (information exchange) özelliğidir. Kişi, talep ettiği kaynaklara başvurduğunda, ilişkili bilgiyi bulmada başarılı ya da başarısız olabilir. Sonuç başarılı olursa, kişi bulduğu bilgiyi kullanır ve bilgi gereksinimi tamamen ya da kısmen karşılanmış olur. Model, bilgi davranışının bir kısmının bilgi alışverişi nedeni ile diğer insanları da içerebileceğini ve yararlı olarak algılanan bilgilerin, başkaları tarafından kullanılabileceğini ileri sürer. Ayrıca yararlı bulunan bilginin kişinin kendisi tarafindan kullanılması veya başkalarına aktarılabilmesi de söz konusudur (Robson ve Robinson, 2013, s. 178; Kundu, 2017, s. 394). Daha önce de açıklandığı gibi, Wilson, oluşturduğu bu ilk modelde (1981), bireyin elde ettiği bilgi ile tatmin olup olmadığı üzerine odaklanmış ancak daha sonra bu modelin eksiklikleri olduğunu düşünmüştür. Şöyle ki, bireyin içinde bulunduğu koşullar, bilgi ararken karşılaştığ1 engeller, elde edilen bilgiyle etkileşimi ve benzeri etmenler belirleyicilikleri nedeni ile dikkate alınmalıdır. Wilson'ın yeni modeli (1996) bu boşlukları doldurmaktadır (Yıldız ve Özenç Uçak, 2014, s. 5). Dolayısıyla, Wilson'ın, önceki modelinde eksik olan ve 1996 yılında geliştirdiği model ile vurgulanan en önemli öge, bilgi davranışı sürecindeki dış/engelleyici etmenler ya da bir diğer deyişle "araya giren değişkenler" faktörüdür. Modelde, bilgi gereksinimlerinin oluştuğu süreçte bilgi edinme engellerinin nasıl geliştiği sorgulanmaktadır. Bunlar psikolojik, demografik, rol ile ilgili, kişilerarası, çevresel ve bilgi kaynağına ilişkin özelliklerdir (Kundu, 2017, s. 395). Wilson'ın bilgi davranışı modelinin önemli özelliklerinden biri, bilgi arayan kişiyi belirli bir "bağlam" içinde ele alması ve bilgi aramaya etki eden bazı 
mekanizmaların varlığına vurgu yapmasıdır. Bu mekanizmaları, daha önce de vurgulandığı gibi, stres/başa çıkma kuramı (stress/coping theory); risk ve ödül kuramı (risk and reward theory) ile sosyal öğrenme kuramı (social learning theory) biçiminde ifade etmektedir. Stres/başa çıkma kuramı ile neden bazı gereksinimlerin bilgi arama ile sonuçlandığı ve bazılarının ise bilgi arama ile sonuçlanmadığına açıklık getirmektedir. Bir hastanın sağlıkla ilgili bir bilgiyi araması ya da tersine bu bilgiyi aramaktan kaçınması buna bir örnektir. Risk ve ödül kuramı için kişinin bir satın alma işlemine karar verme esnasında, riski yüksek olmadığı için bilgi aramaya güdülenmesi örneği verilebilir. Sosyal öğrenme kuramı ise kişinin öz yeterliğine veya belli bir görevi yerine getirecek kapasiteye sahip olduğuna ilişkin inancını ifade etmektedir. $\mathrm{Bu}$, örneğin bir veri tabanı ya da bilgi sistemi aracılığıyla araştırma yapma yetisine olan inanç olabilir (Robson ve Robinson, 2013, s. 179-180).

Greenway (2007, s. 46), Sambo ve diğerleri(2017, s. 2), mahkûmların bilgi gereksinimlerinin genel olarak dışarıdaki halkın bilgi gereksinimleri ile yakınlık gösterdiğini belirtir. Sambo ve diğerleri, (2017, s. 2), bu gereksinimlerin, hayatta kalmak için gereken temel bilgilerden, eğitsel bilgilere ve ruhsal gelişim için gereksinim duyulan eğlenceye yönelik olanlara kadar çeşitlendiğini ileri sürmektedir. Mahkûmların bilgi gereksinimleri, Association for Specialized and Cooperative Library Agencies (ASCLA) tarafindan cezaevlerindeki yetişkinlere yönelik düzenlenen kütüphane standartlarında ise şu şekilde belirlenmiştir: "Cezaevinin düzenleme ve prosedürleri hakkında bilgiler", "dışardaki topluluklarla iletişimi sürdürmek için gereken bilgiler", "mesleki beceriler hakkında bilgiler", "eğitimle ilişkili bilgiler", "rehabilitasyon programlarını destekleyen bilgiler (madde kullanımı gibi)", "yaşam boyu öğrenme ve kişisel gereksinimler için kendi kendine okuma", "rekreasyonel/eğlenme ve dinlenmeye yönelik okuma", "cezaevi sonrası yaşam ve topluma tekrar katılımı destekleyen bilgiler (iş becerileri, barınma vb.)" (Association of Specialized and Cooperative Library Agencies, 1992; akt. Greenway, 2007, s. 46).

Campbell (2005, s. 20), mahkûmların bilgi davranışlarına ilişkin sorgulamalarını şöyle başlatır: "Mahkûmların bilgi gereksinimleri nelerdir? Onlar, açıkçası, en çok nasıl hayatta kalacaklarını ve oradan nasıl çıkabileceklerini merak ederler. Hayatta kalabilmek için kimin güvenilir olduğunu, cezaevi toplumunun onları nasıl kabul edeceğini ve haklarının neler olduğunu bilmeleri gerekir". Yasal hakları ve çıktıkları zaman neler yapabilecekleri gibi konulara ilişkin erişebilecekleri bilgi ortamlarına gereksinim duyarlar. Nitekim literatürde cezaevi kütüphanelerinin rolü en çok bu noktalarda öne çıkmaktadır.

Sambo ve diğerleri, (2017, s. 2) tarafından belirtildiği gibi, aslına bakılırsa, tüm insanlar (cezaevinde olsun olmasin), bir anlamda, benzer bilgi gereksinimlerine sahiptir. $\mathrm{Bu}$ gereksinimler, hayatta kalmak için temel bilgiler, eğitim, sağlıklı yaşam ve eğlenceden ruhsal gelişime kadar çeşitlenmektedir. Bugün cezaevinde olan mahkûmların çoğu, ceza sürelerini doldurduktan sonra topluma geri dönecektir. Bu nedenle, hem cezaevi sorunları ile başa çıkabilmek hem de serbest bırakıldıklarında çeşitli amaçlar için bilgiye gereksinim duymaktadırlar. Onların bilgi gereksinimlerinin karşılanması, kendileri ve toplum için daha iyi vatandaş olmaları ve yeniden sosyalleşmelerine yardımcı olacaktır (Sambo ve diğerleri, 2017, s. 2).

Bilgi ve eğlence kanalları arasında yer alan medya ise mahkûmlar için özel bir yere sahiptir. Bunun nedeni medyanın iki temel etkisidir: cezaevindeki yaşamı dışardaki yaşama 
yakınlaştırabilir; bir diğer deyişle normal hale getirebilir ve mahkûmları toplumdaki değişiklikler hakkında bilgilendirir. Mahkûmlar, örneğin, ortamın rahatsız edici seslerinden uzaklaşmak ve mahremiyet oluşturmak için radyo dinleyebilir, televizyon izleyebilir. Dış dünya ile iletişimde kalmak ve daha az soyutlanmış hissetmek için haberleri takip edebilir. Özgüven ve imajlarını güçlendirmek için tercih ettikleri müzikleri dinleyebilir. Gündelik cezaevi yaşamının monotonluğundan sıyrılmak için kitaplar okuyabilir. Sohbete konu olacak şeyler yakalamak ve yalnızlıktan uzaklaşmak üzere medyayı kullanabilir. Film izleyerek ya da kütüphaneye giderek hücrelerinden çıkabilirler (Vandebosch, 2005, s. 99-100).

Mahkûmların bilgi arayışına en fazla etki eden demografik faktör, eğitimdir. Örneğin, (çalışmada elde edilen bulguların da desteklediği gibi) okuma yazma bilmeyen bir kişinin bilgi davranışları daha çok kişisel bağlantılar ve televizyonu kullanarak bilgi toplamak biçimindedir. Doğal olarak bunlar resmi ve yasal bilginin edinileceği yararlı kaynaklar değildir. Bir diğer demografik sorun dildir. Örneğin, İspanyolca, ABD'de giderek daha fazla mahkûmun konuştuğu bir dildir ancak mevcut bilgilerin çoğu İngilizce'dir (Campbell, 2005, s. 23). Mortensen'e (2015, s. 2) göre, okuma ve yazma becerisi sadece entelektüel bir beceri olarak ele alınmamalıdır çünkü aynı zamanda derin bir sosyal ve kültürel anlamı da vardır. Okuma ve yazma becerisinin olmaması, sosyal katılım, gelişme ve hatta sağlık konusunda dahi sorunlar yaratmakta ve toplumsal dışlanma riskini artırmaktadır. Literatüre dayanan araştırmalar pek çok ülkede cezaevlerinde bulunan mahkûmların genellikle okuryazarlık düzeyi ve eğitim altyapılarının zayıf olduğunu ortaya koymaktadır (Wilhelmus, 1999; Ljodal ve Ra, 2011, s. 484; Gabhann, 2013, s. 19; Mortensen, 2015, s. 2; Garner, 2017a, s. 335-336; Garner, 2017b, s.19, 183; Biju ve Johnson, 2018, s. 73; Sambo ve Ojei, 2018, s. 8; Umamaheswar, 2018; McInerney, 2019, s. 21). Ayrıca, Tarzaan ve diğerleri, (2015, s. 194) eğitim ile tekrar suç işleme arasında anlamlı bir korelasyon olduğunu, eğitimin suç işleme eğilimini azalttığını ifade etmiş ve bu bağlamda kütüphanelerin rolünün de önemli olduğuna işaret etmiştir. Bu nedenle, mahkûmların eğitimine özen gösterilmelidir.

Mahkûmların eğitim düzeyine ilişkin benzer bilgi IFLA tarafından hazırlanan Guidelines for Library Services to Prisoners adlı kılavuzda da vurgulanmaktadır (Lehmann ve Locke, 2005, s. 5):

"Dünyadaki çoğu ülkede, cezaevi ve tutukevi nüfusunu oluşturan bireylerin çoğunluğunun eğitim ve yaşam becerileri sınırlı olup aynı zamanda geçmişlerinde okumanın sık ya da popüler bir alışkanlıklarl olmadığı görülür. Gerçekten de, dikkate değer sayıda mahkûmun düşük okuryazarlık becerileri olduğu ve istihdam edilebilirlik becerilerinin de yeterli olmadığ saptanmıştır. Çok azı daha önce dışarıdaki yaşamlarında halk kütüphaneleri veya üniversite kütüphanelerinin düzenli kullanıcıları olmuştur."

Türkiye'de 137 cezaevi kapsamında yapılan bir araştırmanın (Demir, 2011) sonuçları da benzer bulguları ortaya koymuş ve mahkûmların yarısından fazlasının $(\% 51,3)$ ilkokul ve ilköğretim mezunu olduğu saptanmıştır.

Bouazza (1989) bilgi kullanımının psikologların da üzerinde durduğu gibi bir insan davranışı olmasından yola çıkarak bu davranışı etkileyen etmenleri dikkate almanın önemine işaret etmiştir. Bu etmenlerin bazıları bilgi sistemi ya da kaynağının kendisinden (mevcudiyeti, erişilebilirliği, niteliği, maliyeti, kolay kullanımı vb.) kaynaklanmaktadır. Bazı etmenler ise 
kullanıcıdan kaynaklanmakta olup, bunlara kullanıcının özel uzmanlık ve/veya ilgi alanı, mesleki durumu, onu çevreleyen fiziksel, sosyal, politik ve ekonomik ortamların yanında eğitim düzeyi de örnek verilmektedir (Bouazza, 1989, s. 155-159). Eğitim durumu, insanın bilgi ile iletişiminde, bilgi davranışı ve kullanımında pek çok araştırmacı için diğer değişkenlerin yanında (kişisel, demografik özellikler, inançlar, sosyoekonomik, kültürel durum vb.) önemli bir değişken olarak ele alınmaktadır (Bouazza, 1989; Reading, 2011, s. 127; Agarwal, 2018, s. 62). Bilgi arama davranışına giren bireyin içinde bulunduğu koşullar (mahkûm olmak gibi) bu davranış üzerinde önemli düzeyde belirleyici olduğu gibi, eğitim durumu da bu süreçleri etkileyebilen önemli bir değişkendir.

Yukarıda anılan etmenlerin dışında, Campbell'ın (2005) Wilson'ın modeline ve ağırlıklı olarak Akerström'un (1988) The Social Construction of Snitches adlı çalışmasına dayanarak oluşturduğu çıkarımlar, cezaevlerinde bulunan bireylerin bilgi davranışlarına ilişkin önemli bilgiler verdiği için dikkat çekicidir. Bu nedenle, Campbell'ın (2005) çıkarımlarına ayrıntılı olarak yer verilmesinde yarar vardır. Campbell'a (2005, s. 22) göre, cezaevinde bulunan bireylerin bilgi davranışlarında birtakım değişkenlerin engelleyici rolü dikkate alınmalıdır. $\mathrm{Bu}$ engeller, söz konusu bireylerin bilgi ile etkileşimlerinde sorun oluşturabilmektedir. Sözü edilen engeller şöyle kategorize edilmiştir: "psikolojik", "demografik”, "rolle ilgili veya kişilerarası”, “çevresel”, "kaynak özellikleri”, “risk/ödül kuramı”, "sosyal öğrenme kuramı: öz-yeterlik” ve "bilginin işlenmesi ve kullanımı". Genel olarak bir mahkûmun psikolojik durumuna ilişkin ortaya çıkan ortak özellikler, fevri, aşırı tepkili, manipülatif, ürkek, endişeli olmak biçimindedir. Wisconsin'da bir mahkûm olan Luis Medina, mahkûmların genellikle ilgi, motivasyon, entelektüel açlık ve öğrenme isteklerinin eksikliğini dile getirmektedir (Burt, 1977; Medina, 2000; akt. Campbell, 2005, s. 22). Cezaevinde, bilgi yalnız güvenilir olmayanın (muhbir) kimliğini keşfetmek için değil, aynı zamanda grup normlarını pekiştirmek için de kullanışlı olarak değerlendirilir. Bu grup normlarını oluşturmak ve tanımlamak cezaevi kültürünün temel bir görevidir. Bu nedenle, bilgi arama davranışı, grup odaklı ve grup için değerlidir (Campbell, 2005, s. 30).

Cezaevinin kendine özgü ortamında kişiler arasındaki ilişkiler, bilgi davranışlarını önemli oranda etkileyen dikkat çekici bir etmendir. Bu bağlamda iki tip reaksiyonun yaygınlığı söz konusu olabilmektedir. Bunlar, bilgi paylaşımı ya da tersine içe kapanma, soyutlanma biçimindedir. Ayrıca, kişinin cezaevinin yarattığı kültür çerçevesinde yer aldığı grup içindeki statüsü, bilgiye erişimde ve güvenilirlikte rol oynamaktadır. Buna bir örnek, gardiyan ve mahkûmlar arasındaki bilgi alışverişidir. Bir mahkûmun bilgi sahibi olduğuna ilişkin ipuçlarını isteksizce ve çok nadiren vermesi nedeni ile gardiyanlar daha güvenilir kaynaklar olarak kabul edilmektedir. Ayrıca gardiyanlardan elde edilecek bilgiler, cezaevi kurallarının anlaşılması, cezadan kaçınmak, erken tahliye hakkını kazanmak ve benzeri nedenlerle değerlidir. Mahkûmlar arasındaki statü (eğitim, sosyal konum vb.) farkları da güvenirlilik bağlamında belirleyicidir (Campbell, 2005, s. 23-24). Öte yandan Worley (2011) tarafından verilen birtakım bilgiler mahkûmun bakışı ile resmi bilgi kaynakları olması beklenen cezaevi görevlilerinin konumunu düşündürücü bir boyuta taşımaktadır. Yazar tarafından 32 mahkûmla yüz yüze görüşme sonucu elde edilen veriler, mahkûmlarla cezaevi görevlileri arasında mahkûmun muhbirliğinin hâkim olduğu birtakım çıkar ilişkilerine işaret etmektedir. Böyle bir iklimde mahkûmların paranoyaya varacak düzeyde güvensizlik ve huzursuzluk hissetmesi bilgi 
gereksinimlerinin giderilmesi ve bilgi davranışları bağlamında sorun oluşturma potansiyeline sahiptir (Worley, 2011, s. 82).

Çevresel etmenler, bir diğer önemli konudur. Mahkûmların parmaklıklar arkasında kaldıkları çevreleri aynı zamanda oldukça sınırlı olanaklara sahip olduğundan her anlamda bilgi arama davranışının başarısına zarar verebilmektedir (Campbell, 2005, s. 25). Wilson (1996), erişim, kanal ve güvenilirliği, kaynak özellikleri olarak nitelemekte ve bunu tüketici bilgilerinin incelenmesiyle desteklemektedir. Cezaevi bağlamında, bilgilerin kaynağı, genellikle kişiler arası ilişkilerdir. Bu ilişkilerde en fazla belirleyici öge ise kimin güvenilir olduğu, kimin güvenilir olmadığıdır. Örneğin mahkûmlar bir araya geldiği zaman özellikle aralarından sözü geçen birinin söyledikleri, herhangi bir kanıta dayanmasa da kabullenilmekte; bu kişinin sözleri ile bir kişi muhbir ilan edilebilmektedir. Gruplaşmalar ve grup aidiyeti de bu faktörü tetiklemektedir (Campbell, 2005, s. 27-28).

Wilson (1997, s. 563) konu bağlamında risk bileşenlerinin, performans riski, finansal risk, fiziksel risk, sosyal risk ve ego riski olduğu bilgisini vermektedir. Bu çerçevede, performans ile tüketici tarafından araştırılan ürüne işaret edilir. Tüketici araştırmalarının çoğunda, fiziksel risk bir endişe kaynağı olmaz. Bu, ancak örneğin bir bebek araba koltuğu gibi bir ürünün seçiminde rolü olan, münferit örnekler için geçerlidir. Diğer kategoriler, üzerinde daha fazla durulan risk faktörleridir (sosyal risk ve ego riski). Campbell'a göre (2005, s. 28-29) bu bağlamda, söz konusu mahkûmlar olunca, fiziksel risk hemen her durumda varlık göstermektedir. Yine, bilgi aramanın sosyal riski aynı zamanda bir fiziksel risk niteliği taşımaktadır. Kişilerin birbirine güvensizliği ve şiddete uğrama vb. kaygılar, bilginin, karşılığında bedel ödenebilecek bir öge olmasını koşullandırmaktadır. Bilgi edinmek için verilecek uğraşlar risk taşıdığından, buna değecek midir? Mahkûmların bilgi davranışında finansal risk pek fazla belirleyici değildir ancak örneğin bir mahkûmun diğerine yasal bilgiler vermesi durumunda bunun bir bedeli olabilmektedir. Bu bedel, yalnız para değil sigara veya kahve de olsa sonuç olarak bu bir “finansal risk"tir (Campbell, 2005, s. 28-29).

Wilson'1n (1997, s. 554) üzerinde durduğu bir diğer sosyal kuram, bireyin kendi bilgi, beceri ve yetenekleri ile kapasitesine ilişkin öngörüsünü ifade eden öz-yeterliktir. Ancak Campbell'a göre (2005, s. 29) burada da ilginç olan durum, örneğin yükseköğrenimin iyi bir işe girmenin yolu olduğuna inanan bir mahkûmun, aynı zamanda alabileceği herhangi bir eğitimin kendi istihdamını sağlayamayacağına ilişkin inancıdır. Cezaevi kültürünün mahkûmda yarattığı edilgenlik, savunmasızlık ve güçsüzlük duygusu, eğitim ve bilgiye inancı ile bilgi davranışlarının niteliğini olumsuz etkilemektedir (Campbell, 2005, s. 29).

\section{Mahkûmların Bilgi Gereksinimi, Bilgi Davranışı ve İlişkili Etmenler: Çeşitli Ülkelere İlişkin Örnekler}

Çalışmanın bundan sonraki kısmında, mahkûmların bilgi gereksinimleri, bilgi davranışları ve ilişkili etmenler, uluslararası literatürden elde edilen ve genellikle alan araştırmalarına dayanan bulgular çerçevesinde değerlendirilmektedir. Aşağıda sırası ile konu bağlamında literatürde öne çıkan ülkeler olduğu için Amerika Birleşik Devletleri, İrlanda, İskoçya, Malezya, Sri Lanka, Hırvatistan ve Nijerya'daki durum açıklanmaktadır. 


\section{Amerika Birleșik Devletleri}

Wilhelmus (1999, s. 117) cezaevlerinde mahkûmların bilgi gereksinimlerini karşılamada en fazla engelleyici etmenlerden birinin internet erişimine izin verilmemesi olduğuna değinerek aynı zamanda mektuplara uygulanan sansürün de sorun olduğuna işaret etmiştir. Visher ve Lattimore (2007, s. 31) tarafından ve çoğunluğunu Afrikalı Amerikalıların oluşturduğu mahkûmlar ile yapılan bir çalışmada elde edilen bulgular, cezaevi sonrası yaşam için en çok duyulan bilgi gereksinimlerinin eğitsel nitelikli ve sürücü ehliyeti almak, meslek edinmek, istihdam gibi gündelik yaşamlarına ilişkin olduğunu göstermiştir. Drabinski ve Rabina (2015) tarafindan New York Halk Kütüphanesinde cezaevleri ve tutukevlerine referans hizmeti veren bir program (Correctional Services Program) çerçevesinde mahkûmlardan mektuplarla gelen refererans sorularının bir içerik analizi yapılmış ve mahkûmların bilgi gereksinimleri belirlenmiştir. Gereksinim duyulan bilgilerin ağırlıklı olarak kişisel gelişim ve çeşitli genel referans soruları olduğu ve internet erişimi vb. olanakların eksikliği nedeni ile bilgi gereksinimlerinin genellikle giderilemediği sonucuna varılmıştır. Drabinski ve Rabina'nın (2015, s. 45) verdiği bilgilere göre, Amerika Birleşik Devletleri’nde mahkûmların bilgi gereksinimleri, ağırlıklı olarak, suçu sabit görülüp ceza almış, ceza süresinin belirli kısmını cezaevinde geçirmiş ve serbest bırakılmadan önce, topluma yeniden katılmaya hazırlık aşamasında denetimli olarak yaşanılan ve halfway house denilen evler hakkında bilgiler, sosyal güvenlik ve güncel yaşam konuları, serbestlikle beraber iş bulma, tıbbi bakım bilgileri ve davalarına ilişkin destek (kendi kendine mektup yazma becerisi edinme gibi) vb. taleplerdir. Genel olarak referans soruları bağlamında ise mahkûm sorgulamaları, beyzbol istatistiklerinden sinirbilim (neuroscience) konularına kadar çeşitlenebilmektedir. Drabinski ve Rabina' ya (2015, s. 47) göre, bilgi yoksulluğu mahkûmların önemli bir sorunudur. İnternete erişimin olmamasının yanında sınırlı kütüphane hizmetleri bu sorunun en önemli kaynağıdır. Mahkûmların, dış kaynaklar (bilgi uzmanları, çeşitli gönüllü hizmetler) olmaksızın bilgi gereksinimlerini karşılamaları güçleşmektedir. Ayrıca hapsolmanın kendisi, kişisel gelişim, kendi kendine birtakım şeyleri yapabilme, hem cezaevinde hem de dişarda iş olanaklarına ilişkin olanlar başta gelmek üzere özel bir takım bilgi gereksinimlerini ortaya çıkarmakta ancak bunların çoğu giderilememektedir.

Bingman-Forshey ve Gibbons (2020) mahkûmların mahkeme ve davalarına ilişkin bilgi gereksinimlerinin yoğunluğuna işaret etmiş ve dış dünyada hızla gelişen internet dâhil yeni teknolojilerin sunduğu olanakların mahkûmlar tarafından kullanılmaması ile cezaevinin kurallı yapısına vurgu yapmıştır. Bu etmenlerin dışında mahkûmların okuma ve bilgi gereksinimlerinin önünde engel olarak sorun oluşturan bir diğer konu sansürdür. Kurumlar içerisinde yayınları incelemekle sorumlu komiteler bulunmakta ve belli kategoride yayınları elemektedir. Bunlar örneğin, silah veya uyuşturucu üretimi ile ilgili yayınlar ve kaçış teşebbüsüne yardımcı olacağı düşünüldüğü için haritalar vb. dir (Bingman-Forshey ve Gibbons, 2020, s. 68).

\section{Irlanda}

McInerney (2019, s. 22) Mountjoy, İrlanda'da bulunan mahkûmların bilgi gereksinimlerini araştırdığ 1 ve Kütüphane ve Bilgibilim alanında master tezine dayanan çalışmasında mahkûmların bilgi gereksinimlerinin arasında en popüler olanın kendi kendine yardım kitapları (self-help books) olduğunu saptamıştır. Bunu, olgulara veya tarihi gerçeklere dayanan/kurgusal 
olmayan yazın türleri ve romanlar izlemektedir. Sesli kitaplar, DVD'ler ve yabancı dil materyaller daha az kullanılan materyallerdir. Ancak bunun nedeni, örneğin DVD'lerin ilgi görmesine karşın kaynak yetersizliği nedeni ile cezaevi kütüphanesinde bulunmamasıdır.

\section{Ískoçya}

Scott, (2016) tarafından İskoçya'nın Shotts yakınlarındaki bir cezaevinden (HMP Shotts) 12 mahkûmla 2-3 haftadan çok süren görüşmeler sonucunda elde edilen verilere göre mahkûmların bilgi gereksinimleri yoğunluk sırası ile şunlardır: Eğitsel (Öğrenme Merkezinde eğitim görenlerin eğitimlerine ilişkin vb. konular); gündelik (özellikle cezaevine yeni gelenlerin öğrenmek istediği akşam yemeği menüsü, telefonlaşma, ziyaretlerin düzenlenmesi ve çamaşır saatleri gibi cezaevi ortamındaki pratik bilgiler); sağlık (çeşitli sağlık problemlerine ilişkin bilgiler arasında organ bağışı hakkında bilgi talepleri dahi vardır); hukuk (yasal öneri ve destek istekleri); duygusal (yakınlara duyulan özlem, depresyon, endişe vb. problemleri aşmak için gereksinim duyulan bilgiler); finansal (banka hesapları, sigorta vb. işlemler); iş (mesleki eğitim alma talebi de dâhil serbestlik sonrası iş kaygısı, iş bulma yöntemleri, iş seçenekleri vb. bilgiler) ve ikamet (serbestlik sonrası kiracı ya da ev sahibi olma konusunda) bilgiler (Scott, 2016, s. 3438). En çok başvurulan bilgi kaynakları ise sırası ile öğretmenler, aile ve yakınlar, diğer mahkûmlar (bu noktada bilgilerin saptırılması, yanlış bilgi verilmesi vb. sorunlar devreye girebilmektedir), cezaevi görevlileri, kütüphaneciler, sağlık görevlileri, kitaplar (sağlık ve eğitim konusunda başvurulmakta ancak güncel olmadıklarından yakınılmaktadır), televizyon ve radyo (dış dünya ve güncel olayların farkında olmak için tercih edilmekte ancak bazı kanalların yasaklanmış olmasından yakınılmaktadır), papaz vb. din görevlileri (mahkûmlar dini bilgilere ilişkin destekleri yanında en çok kendilerine ilişkin ön yargıları olmadığı ve kendilerini iyi hissettirdiği için din görevlilerini tercih etmektedir), sosyal hizmet görevlileri (ancak mahkûmlar arasında suç işledikleri için sosyal hizmet görevlilerinin kendilerini kategorize ettiğini düşünenler de vardır), Ansiklopedi Yazılımı (Encyclopedia Software) (mahkûmların bazıları bu kaynağı fazla eski ya da Amerikan odaklı bulmakta, bazıları da yararlı olduğunu düşünmektedir), cezaevi kuralları (mahkûmların kendilerine ilişkin yaptırımlar vb. konularda gerçek ve güvenilir kaynak olarak görülse de bazı mahkûmlar anlamak ve yorumlamakta güçlük çekebilmektedir) ve ilanlar (güncellenme süreçleri ağır olduğu için sorunlu bulunmaktadır (Scott, 2016, s. 38-45). Mahkûmların bilgi arama davranışlarının önündeki engeller ise sırasıyla internetin eksikliği (özellikle açık üniversite öğrencileri ve üniversiteye hazırlananlar için önemli bir kaynak olması ve güncel bilgi edinmeyi engellemesi açısından sorun oluşturmaktadır), etiketlenme kaygısı (stigma) ve ön yargılar (mahkûmların cezaevi görevlileri ile bilgi paylaşımında bulunma durumunda diğer mahkûmların onlardan şüphe etmeleri, muhbirlikle suçlamaları kaygısı, öğretmenlere soru yöneltecekleri zaman zekâ sorunları olduğu biçiminde algılanma korkusu, sağlık görevlileri tarafından madde kullandıklarına ilişkin ön yargılar vb.), telefon (telefon konuşulan ortamların mahremiyete izin vermemesi, telefonların denetlenerek kayıt altına alınması vb. sorunlar), öz saygı ve güven eksikliği (mahkûmların kendilerine ilişkin imaj kaygısı, suçluluk duygusu, kendilerini yük gibi görmeleri vb. duygusal engeller), güvensizlik (mahkûmların cezaevi görevlileri tarafından dikkate alınmama, kendileri ile alay edilmesi kaygısının yanı sıra diğer mahkûmlara duyulan güvensizlik nedeni ile ilişkilerde mesafeli ve temkinli olma vb.), fiziksel sınırlar (hücre hapsi vb. fiziksel sınırlamalar 
ve bu ortamın yarattığı ruhsal problemler) ve coğrafi uzaklıktır (aile ve yakınları çok uzakta olan mahkûmların yaşadığı sorunlar) (Scott, 2016, s. 46- 51).

Canning ve Buchanan (2019, s. 421-422) tarafından yüksek güvenlikli bir cezaevinde gerek yaşları 18 ile 54 arasında değişen 12 mahkûm gerekse personelden edinilen bilgilere göre, mahkûmların en yoğun bilgi gereksinimleri, eğitim, sağlık, cezaevinin rutinleri ve kuralları (iş ve yemek saatleri ya da telefonla görüşme izni vb.), yasal hakları ve mevzuata ilişkin konular, serbest bırakıldıkları zamana ilişkin kaygılarından kaynaklanan finans, ikamet, iş bulma vb. konulardadır. Mahkûmlarla görüşmeler sonunda yapılan değerlendirme, sayılan tüm bu gereksinimlerin yeterince karşılanmadığı yönündedir. Yine mahkûmlardan alınan bilgilere göre, en çok başvurulan bilgi kaynakları, cezaevi personeli, öğretmenler, kütüphaneciler, sağlık profesyonelleri, kurum papazları, sosyal hizmet uzmanları, diğer mahkûmlar ve ailedir. Canning ve Buchanan (2019, s. 430-431) mahkûmların bilgi davranışlarına olumsuz etki eden etmenlerin ise mahkûmların özgüven sorunu da dâhil duyuşsal durumlarından kaynaklandığı, güven sorunu ve güvenlik kaygısının buna eşlik ettiği, özellikle uzaktan eğitim alan mahkûm için internet erişimine izin verilmemesinin de sıkıntı yarattığını ileri sürmektedir.

\section{Malezya}

Rafedzi ve diğerleri (2016) tarafından yapılan çalışma, Malezya'daki beş ıslah evinde bulunan çocukların bilgi gereksinimleri ve davranışlarına ilişkin genel bir çerçeve sunması anlamında önemlidir. Söz konusu ıslah evlerinde bulunan kütüphanelerin bilgi gereksinimlerine yanıt verip veremediğinin de sorgulandığı çalışmada veri toplama aracı olarak yerinde gözlem ve görüşme tekniği kullanılmıştır. Örneklem olarak seçilen (evren: 2010) grup 13-21 yaş aralığında 27 çocuktan oluşmaktadır. Genç mahkûmların çoğunluğu okumanın dış dünyadaki yaşamları boyunca onlar için bir hobi ya da ilgi olmadığını kabul etmişlerdir (Rafedzi ve diğerleri, 2016, s. 102). Genç mahkûmların hepsi kendilerini daha iyi hissettirdiği ve streslerini azalttığı için çizgi romanların ve dergilerin en iyi okuma materyalleri olduğu görüşündedirler. Ancak bu kaynaklar cezaevlerinin kütüphaneleri tarafından kabul edilmemektedir. Malezya'da genel olarak çizgi romanlar gençler ve çocuklar için en çok sevilen okuma materyalleridir. Mahkûmlar ayrıca, dergi ve gazete okumak için de güçlü bir istek duyduklarını ifade etmişlerdir. Özellikle gazeteler güncel haberleri verdiği ve dış dünya ile bağlantı kurmayı kolaylaştırdığı için rehabilitasyon sürecinde çok önemlidir. Bununla beraber gazeteler sslah evlerine gecikmeli girdiğinden mahkûmlar güncel haberleri ancak bir ay sonra okumaktan yakınmaktadır. (Rafedzi ve diğerleri, 2016, s. 102). Mahkûmların bilgi gereksinimleri daha çok sürdürdükleri eğitimleri ve ilgi alanlarına bağlıdır. Bunun dışında cezaevinde zaman geçirmelerini sağlayacak materyalleri talep etmektedirler. Bilgi davranışlarında gözlemlenen başarısızlıkların özellikle yanlış kaynak seçimleri ile kendini gösterdiği, bunun nedeninin mahkûmların isteksizliği olmadığı saptanmıştır. Cezaevi kütüphanelerinin eksiklikleri, güncel olmayan ve gereksinimleri karşılayamayan koleksiyonları ile cezaevi yöneticilerinin bilgisizliği ve farkındalık eksikliği de bu anlamda önemli etkenlerdir. Mahkûmların, bilgi arama süreçlerinde cezaevi öğretmenleri ve görevlileri ile daha fazla iş birliğine dayalı bir ortam içinde etkileşime girme olanaklarının sunulması önerilmektedir (Rafedzi ve diğerleri, 2016, s. 103107). 
Rafedzi ve diğerleri(2018) tarafından yapılan ve Malezya'da bulunan genç mahkûmlara ilişkin bir diğer çalışmada, mahkûmların bilgi gereksinimlerinde eğitsel niteliğin öne çıktığı çünkü çoğunluğunun eğitimini yarıda bırakarak mahkûm olduğu ifade edilmektedir. Ayrıca, Rafedzi ve diğerleri, (2018, s. 89), mahkûmların, dışardaki vatandaşlarla aynı eğitim olanaklarından yararlandıklarını ifade etmektedir. Bu mahkûmlar, cezaevi ile iş birliği içinde olan Milli Eğitim Bakanlığına bağlı özel bir program kapsamında örgün eğitimlerini sürdürmekte ve kamusal ortamda sınavlara girmelerine izin verilmektedir. Suç faaliyetlerinin tekrarlanmamasında eğitime önem verilmekte ve 21 yaş ve altındaki genç mahkûmların eğitimi için cezaevlerine öğretmen gönderilmektedir. Çalışmada ayrıca genç suçluların cezaevi dışında gelişen dünya çapındaki sorunlara karşı duyarlı olmalarının gelecekteki yaşamları için önemine de vurgu yapmaktadır (Rafedzi ve diğerleri, 2018, s. 98). Burada da yukarıdaki çalışmada olduğu gibi, mahkûmların bilgi arama davranışlarının başarısızlığına en fazla yol açan etmenin mahkûmların bu anlamdaki isteksizliğinden ya da başarısızlığından değil cezaevi kurumunun sağladığı bilgi kaynak ve kanallarının uygun olmamasından kaynaklandığının altı çizilmektedir (Rafedzi ve diğerleri, 2018, s. 87).

\section{Sri Lanka}

Chandani'nin (2019a) Sri Lanka'da bir cezaevinde (Welikada Prison) 5 rehabilitasyon ve kütüphane görevlisi ve 10 mahkûmla, nitel bir veri toplama tekniği olan odak grup görüşmesiyle yaptığı çalışmada elde ettiği bulgulara göre, cezaevinde bulunan iki kütüphane, mahkûmların bilgi gereksinimlerini karşılayacak niteliklerden yoksundur. Mahkûmların bilgi gereksinimlerinin yeterince karşılanmasını engelleyen etmenlerin başında cezaevinin rahatsız edici nitelikleri, cezaevi ve kütüphanesinin bütçe sorunu ve kütüphane mekânının elverişsizliği gelmektedir. Bunların dışındaki sorunlar, cezaevi politikaları, personel sorunu, mahkûmların bilgi kaynaklarını ve hizmetlerini kullanımı için çok az zaman ayrılması ile halk kütüphaneleri ve ilişkili meslek kuruluşları ile bağlantıların zayıf olmasıdır (Chandani, 2019a, s. 72).

Chandani (2019b) tarafindan yine aynı cezaevinde (kurum hem Welikada Prison hem de Magazine Prison adları ile tanınmıştır ve yüksek güvenlikli bir kurumdur) yapılan bir çalışmasında ise örneklem alınan 100 mahkûma (2018 yılı verilerine göre Welikada/Magazine cezaevinde 8868, Sri Lanka genelinde ise toplam 121.869 mahkûm bulunmaktadır) anket uygulanmıştır. Çalışmada, mahkûmların bilgi gereksinimleri ve bu gereksinimlerin ne ölçüde karşılandığı, cezaevi kütüphanelerinin bilgi kaynakları ve hizmetleri ve bu bağlamda karşılaşılan sorunlar araştırılmış, öneriler sunulmuştur. Mahkûmların bilgi gereksinimleri arasında "çok fazla gereksinim duyuluyor" biçiminde belirtilenler, sırasıyla din $(\% 63,8)$, sağlık $(\% 62,5)$, finansal $(\% 62,5)$, yasal $(\% 61,2)$, haberler $(\% 52,5)$, hikâyeler $(\% 40)$ ve genel bilgilerdir (\% 37,5) (Chandani, 2019b, s. 152). Toplam 3335 kitab1 olan kütüphanenin kaynaklarının çoğu roman ve hikâye kitapları $(\% 49,4)$ ile dini kitaplardır (\%33). Yalnız 5 adet $(\% 0,14)$ ansiklopedi ve sözlük gibi başvuru eserleri bulunmaktadır. Sınırlı sayıda belirli disiplin ya da alanlara ilişkin olan kitapların ise güncel olmadığı ve yıllar önce halk kütüphanesi tarafından bağışlandığı belirtilmişstir. Cezaevi yetkilileri güvenlik nedeniyle gazete ve dergi almamaktadır (Chandani, 2019b, s. 152).

Çalışmanın bulguları, cezaevine ziyarete gelen dini kurumlar ve gruplar tarafından sunulan bilgi kaynakları ve hizmetleri ile mahkûmların dini bağlamda bilgi gereksinimlerinin 
büyük ölçüde karşılandığını göstermiş̧tir. Eğitim, sağlık ve mesleki bilgi gereksinimleri orta düzeyde, finansal bilgi gereksinimleri düşük düzeyde karşılanmaktadır. Mahkûmlar bilgi gereksinimlerinin arzu ettikleri düzeyde karşılanamamasında yeterli kütüphane ve bilgi kaynaklarının bulunmayışının temel etmen olduğu görüşündedir. Kütüphanenin bütçe ve kaynak yetersizliğinin yanında cezaevinin baskı oluşturan doğası, sansür, kalifiye personel olmaması, mahkûmların bilgi kaynaklarına ulaşmak için zamanlarının yetersiz olması, mekanların elverişsizliği ve halk kütüphanesi dâhil diğer kütüphaneler ve meslek organizasyonlarıyla kurulan bağlantının zayıflı̆̆ gibi etmenler mevcut sorunları pekiştirmektedir (Chandani, 2019b, s. 153).

Cezaevindeki aydınlatma, gürültü vb. sorunların ele alınması ve çözümü, mahkûmların yasal destek alması, zamanı etkin kullanması ve rehabilitasyonu için kütüphanenin ülke çapında diğer cezaevleri ve kütüphane dernekleri ile iş birliği yapması, ödünç verme hizmeti vb. olanaklar bağlamında halk kütüphanesi ile entegre olunması, profesyonel kütüphanecilerin desteğini de alarak simüle edilmiş internet hizmetlerinin (simulated internet service) tasarlanması vb. çözümler önerilmektedir (Chandani, 2019b, s. 154-155).

\section{Hirvatistan}

Bajić, (2015, s. 525) tarafından Hırvatistan'da yapılan bir araştırmanın sonuçlarına göre, mahkûmların bilgi gereksinimlerine ilişkin elde edilen bulgular arasında, çoğunluğu, mahkûmun haklarına ilişkin konular $(\% 56,3)$, aile ve yakınlarla ilgili bilgiler $(\% 50,6)$ ile hapis sonrası yaşam konusu $(\% 49,4)$ ve iş bulma $(\% 39,5)$ konusu oluşturmaktadır. Bunların dişında gereksinim duyulan bilgiler; cezaevi kuralları $(\% 38,3)$, spor $(\% 32,7)$, cezaevinin dışındaki yaşam $(\% 32,1)$, parasal konular $(\% 31,3)$, sağlı $(\% 30)$, yasal uygulamalar $(\% 29)$, eğitimöğretim $(\% 23,2)$, güncel olaylar $(\% 21,6)$, mahkûmun kendi yasal durumu $(\% 19,8)$, kültürel olay ve etkinlikler $(\% 18,7)$, dini bilgiler $(\% 16,3)$, psikoloji $(\% 15,5)$, şarkıcı, aktör, politikacı vb. tanınmış kişiler hakkında bilgiler $(\% 8,7)$ ve diğer konulardır $(\% 5,8)$. Mahkûmların bilgi kaynağı olarak ağırlıklı oranlarda aileleri ve arkadaşlarına $(\% 60,3)$ ve cezaevi görevlilerine $(\% 57,9)$ başvurdukları ortaya çıkmıştır. Söz konusu başvurulan bu bilgi kaynaklarını, diğer mahkûmlar $(\% 35,9)$, kitap, gazete ve avukatlar $(\% 31,3)$ izlemektedir. Kütüphaneyi başvuru kaynağı olarak seçenlerin oranı $(\% 4,8)$ ise çok düşüktür. Aynı çalışmanın (s. 526) bulgularına göre, mahkûmların büyük çoğunluğu bilgisayar ve internetin olmaması nedeni ile bilgi gereksinimlerini rahatlıkla karşılayamadıklarından yakınmıştır.

\section{Nijerya}

Eze (2015, s. 285-298), cezaevlerinin sınırlar oluşturan politikaları, kütüphanelerinin bütçelerinin kısıtlı olması, güncel, popüler yayınların (en çok satanlar vb.) pahalılığı ve bir yandan da okuma materyallerinin sansürlenmesi nedeniyle mahkûmların bilgi gereksinimlerinin yeterince karşılanamamasına vurgu yapmaktadır. Ayrıca mahkûmlardan alınan dönütler, çoğu durumda, okuma materyalleri sağlansa bile, cezaevlerindeki sınırlı ve rahatsızlık veren ortamların sorun yarattığını göstermektedir. Cezaevi, mahkûmlara bilgi kaynak ve ortamlarını sağlamaktan çok onları hapis etmeye odaklıdır. Omolola (2015) tarafından Nijerya'da 229 mahkûma yöneltilen anket sorularının ortaya koyduğu verilere göre, mahkûmların bilgi gereksinimleri yoğunluk sırası ile ele alındığında, en yüksek oran çeşitli bilgi 
ve beceriler edinme gereksinimidir $(\% 63,8)$. Arkasından, eğitsel kaynaklara ve bilgilere gereksinim $(\% 49,2)$ ile eğlence $(\% 48,1)$ gelmektedir. Daha düşük yoğunluk yasal konulardaki bilgi gereksinimi $(\% 23,2)$, ahlaki bilgi $(\% 25,9)$ ve kültürel bilgilerdir $(\% 17,3)$ (Omolola, 2015, s. 72). Aynı çalışmada elde edilen veriler, kitapların en çok kullanılan $(\% 72,4)$ bilgi kaynakları olduğunu ortaya koymuştur. Bunun nedeni, kitapların tüm cezaevi kütüphanelerinde en fazla bulunan kaynaklar olmasıdır. Sözlük kullanımı $(\% 60,5)$ ile gazete kullanımı da $(\% 54)$ yüksek oranlardadır. Ancak kütüphanelerde bulunan geriye kalan kaynak türlerinin kullanılmamasının nedeni mahkûmların o kaynakları gereksinimleri ile ilgili bulmamalarıdır (Omolola, 2015, s. 67). Omolola (2015, s. 78), cezaevlerinde bulunan kaynakların kitaplar, gazeteler, ansiklopediler ve sözlüklerle sınırlı kalmasını eleştirmekte ve cezaevlerine halk kütüphanelerinin de desteğiyle hem basılı hem de basılı olmayan medyanın ulaştırılması gerektiğini ifade etmektedir. Ayrıca din, sanat ve zanaat, tarih, coğrafya, dil, şiir gibi içerikleri olan kaynakların da olmasının gerekliliğine işaret etmektedir.

Tarzaan ve diğerleri, (2015) orta güvenlikli bir cezaevinde (Makurdi Cezaevi) 90 mahkûma anket uygulayarak yaptıkları çalışmada, mahkûmların bilgi gereksinim ve davranışlarının diğer vatandaşlarınkilere benzediğini ve kişiden kişiye de değiştiğini ileri sürmektedir. Mahkûmların bilgi gereksinimleri içerisinde en yoğun olanı sağlık bilgileri $(\% 31,5)$ ile yasal $(\% 13,5)$ ve eğitsel bilgilerdir $(\% 13,5)$. Bunları dini bilgiler $(\% 9)$, mesleki bilgiler $(\% 8,1)$ ve eğlence ile dinlenmeye ilişkin bilgiler takip etmektedir $(\% 5,4)$. En fazla başvurulan bilgi kaynakları ise avukatlar (\%27) ve televizyon yayınlarıdır $(\% 25,2)$. Daha sonra ise sırasıyla cezaevi görevlileri $(\% 10,8)$, sağlık görevlileri $(\% 9)$, ilan panoları ve posterler $(\% 5,4)$ ile dini mekanizmalar gelmektedir $(\% 3,6)$ (Tarzaan ve diğerleri., 2015, s. 196). Aynı çalışmanın sonuçlarına göre, bilgiye erişimin önündeki engeller arasında en ağırlıklı olanı radyo/televizyon programlarının İngilizce olması (\%27) ve düşük okuryazarlık düzeyidir (\%18). Diğer sorunlar sırasıyla bilgi sistemleri $(\% 13,5)$ ve kütüphane hizmetlerinin eksikliği $(\% 10,8)$, farkındalık eksikliği (\%9) ve bilgi materyallerinin pahalılığıdır (\%2,7). Ĕgitsel bilgiler arasında en fazla gereksinim duyulan bilgiler; yasalara $(\% 30,6)$, sağlığa $(\% 18,9)$ ve mesleki eğitime (\%18) ilişkin olanlardır. Diğerleri ise sırasıyla dini eğitim (\%9) ve temel okuryazarlık bilgileridir (\%4,5) (Tarzaan ve diğerleri, 2015, s. 196-197).

Emasealu ve Popoola (2016, s. 2) tarafindan Nijerya'da 374 mahkûm ile gerçekleştirilen anket araştırmasını kapsayan çalışmada mahkûmların bilgi gereksinimlerinin karşılanması ile psikolojik durumlarının iyileşmesi arasında anlamlı ve çoklu korelasyon ilişkisi olduğu belirtilmektedir. Aynı çalışmada (s. 10-13) 4'lü Likert ölçeğine göre mahkûmlardan alınan yanıtlar en fazla gereksinim duyulan bilgileri göstermektedir. Bunlar öncelik sirasıyla; yasalara ilişkin destekleyici bilgiler, çeşitli bilgi ve beceriler, sağlik, eğitim, yaşam boyu öğrenim, eğlence ve dinlenmeye ilişkin konular, kişisel gelişim, ruhsal gereksinimler ve ekonomiye ilişkin bilgilerdir. Çalışma, Nijerya'daki cezaevlerinde mahkûmların psikolojisini desteklemesi bağlamında da önemli olan sözlük, ansiklopedi, bibliyografya, rehber ve hatta roman gibi önemli bilgi kaynakların çoğuna erişim sorununu ortaya koymuştur. Cezaevlerinde güvenlik gerekçesi ile haritalar, atlaslar gibi materyallerin yanı sıra internet erişilebilirliğine getirilen yüksek kısıtlamalar söz konusudur. Ayrıca kütüphanelerde bulunan kaynakların mahkûm gereksinimleri ile ilgisiz ve eski olması, güncel olmaması da işaret edilen bir sorundur. Emasealu ve Popoola (2016, s. 12) Nijerya'daki çoğu mahkûmun cezaevine girdiği zaman 
eğitimlerinin yarım kaldığı, ortaöğretimden ayrılan çok sayıda mahkûmun yanı sıra yükseköğretimden ayrılan çok sayıda mahkûmun da olduğunu ileri sürmektedir. Yazarlara göre, yüksek öğretimde çeşitli disiplin alanlarından (tıp, mühendislik, askerlik, beşeri ve sosyal bilimler, polislik ve hukuk gibi) gelen mahkûmlar da dahil tüm mahkûmların hem eğitimlerini hem de ruhsal gelişimlerini desteklemek kurumun görevi olmalı, bu nedenle bilgi kaynakları güncellenmeli ve geliştirilmelidir.

Eze'nin (2016) çalışmasında, mahkûmların gereksinim duyduğu bilgiler, bu gereksinimlere yanıt verebilecek kütüphane ve bilgi hizmetleri olup olmadığg ve mahkûmların bilgi gereksinimlerinin ne ölçüde karşılandığı araştırılmıştır. Veri toplamak için, çoktan seçmeli anket soruları kullanılmış ve odak grup görüşmesi yapılmıştır. Eze'nin (2016, s. 245-246) verdiği bilgilere göre, çalışma Nijerya'nın Güneydoğu jeopolitik bölgesinin beş eyaletinin cezaevlerinde yapılmıştır (Abia, Anambra, Ebonyi, Enugu ve Imo eyaletleri). Söz konusu beş eyalette 14 cezaevi bulunmaktadir. Nijerya Cezaevi Servisine (Nigerian Prison Service) göre, çalışma sırasında Güneydoğu bölgesinde 21 sosyal hizmet görevlisi ve kütüphane çalışanı ile 6891 mahkûm bulunmaktadır. Çalışmanın örneklemi 1095 mahkûm ve 21 kütüphaneci ile sosyal hizmet görevlisi dahil toplam 1116 kişidir.

Kütüphaneci ve sosyal hizmet görevlilerinin bakış açılarına göre, mahkûmların en yüksek düzeyde bilgi gereksinimleri; kendi kendilerine öğrenme (self learning), güncel olaylar, ruhsal gelişim, ilkyardım vb. sağlık konularıdır. Bunu, yoğunluk sırasıyla temel hijyen sağlama bilgileri, çeşitli beceriler, duygusal gelişim ve eğlence konuları izlemektedir. Arkasından da finansal konular gelmektedir (Eze, 2016, s. 246).

Odak grup görüşmesi ile mahkûmların kendilerinden bilgiye gereksinim duydukları alanlar ve gereksinimlerinin gerekçeleri öğrenilmeye çalışılmıştır. Farklı cezaevlerinden farklı grupların yanıtları, mahkûmların yukarıda belirtilen tüm alanlar hakkında bilgiye gereksinim duyduğunu göstermiştir (Eze, 2016, s. 246). Mahkûmlar, ruhsal ve duygusal olarak örneğin, kutsal kitaplar gibi dini konularda okuma kaynaklarına ve azizler gibi örnek yaşamları olan kişilerin hikâyelerine ve biyografilerine ilgi duyduklarını belirtmişlerdir. Tüm gruplar, temel insan hakları dâhil kendi davalarına ilişkin konular vb. yasal bilgilere çok fazla gereksinim duyduklarını ifade etmiştir. Yine, grupların çoğu ayrıca eğitsel bilgi gereksinimlerini dile getirmiş ve cezaevine girmeden önce yükseköğrenim görmüş olanlar dışındaki kişiler farklı amaçlar için daha fazla eğitim almaları gerektiğini belirtmiştir. Eğlendirici, dinlendirici materyaller ve okumaya ilişkin de yoğun bir talep olduğu anlaşılmıştır (Eze, 2016, s. 247). Bilgi kaynağı olarak kullanılan kütüphanelerde mahkûmlara ödünç verme hizmetleri olduğu ancak bu hizmetlerin yeterli düzeyde sağlanamadı̆̆ı gözlemlenmiştir. Daha çok bağışlar yoluyla sağlanan kütüphane materyallerinin güncel olmaması ve cezaevlerindeki güvenlik kaygısı odaklı baskı iklimi ile sansür, mahkûmların bilgi gereksinimleri ile bilgi davranışlarını olumsuz anlamda etkileyen etmenlerdir (Eze, 2016, s. 248). Mahkûmların bilgi gereksinimlerini karşılama anlamında, birincil sorumluluğu olan cezaevi yetkilileri yerine STK'lar, dini gruplar ve ilgili kişilerin desteğinin yoğun olması dikkat çekici bir bilgidir (Eze, 2016, s. 251).

Sambo ve diğerleri, (2017, s. 1-2) tarafindan Nijerya'da dört cezaevinde 936 mahkûm ile yapılan çalışmadan elde edilen bulgular, mahkûmların bilgi gereksinimlerinin en fazla sağlık koşulları ve finansal konulara ilişkin (\%99) olduğunu ortaya koymuştur. Bunları; manevi ve ahlaki konular (\%88) ile cezaevi sonrası yaşama ilişkin mevzuat vb. konular hakkında bilgi 
(\%86), aile/arkadaşlar (\%68), okuryazarlık eğitimi (\%65) izlemektedir. Gereksinim duyulan diğer konular ise sırasıyla; çeşitli bilgi beceri edinimleri (\%63), cezaevlerindeki hakları (\%42), cezaevi kuralları (\%34) ve diğer konulardır (\%26). Aynı çalışmanın bulgularına göre, mahkûmların en fazla bilgi gereksinimlerini karşıladıkları kaynaklar, oldukça yüksek bir oranla (\%75) cami veya kiliselerdir. Bu kaynakları, aile ve arkadaşlar (\%65), doktor ve hemşireler ile diğer kaynaklar (\%15) izlemektedir. Kütüphane aracılığıyla bilgi gereksinimi karşılamaya ilişkin oranın düşüklüğü (\%11) dikkat çekicidir. Bunun nedeni, muhtemelen, mahkûmların çoğunluğunun (\%85) kütüphane koşullarını yetersiz bulmalarıdır. Mahkûmların bilgi arama davranışını etkileyen faktörler arasında en etkin olanı ise cezaevinin rahatsız edici doğası ve ortamı, mahkemelerin uzun süreli ertelemeleri (\%97) gelmektedir. Hem kütüphane hem de cezaevinin yetersiz bütçe ile ayakta durmaya çalışmasından doğan nitelikler (\%95) ile beraber kütüphane için kullanılan mekanın elverişsizliği (\%85) diğer sorun oluşturan etmenlerdir (Sambo ve diğerleri, 2017, s. 1-2).

Emasealu'un (2018, s. 40-42) Nijerya'da iki cezaevinden (Kuje ve Kaduna) rastgele seçilmiş 898 mahkûmu örneklem alan çalışmasında, mahkûmların bilgi gereksinimleri, kütüphanelerin bu bağlamda işlevselliği ve ilişsili etmenler sorgulanmıştır. Bilgi gereksinimleri içerisinde en ağırlıklı olanları, sırasıyla; sağlı (\%100), çeşitli beceriler edinme (\%100), yasal destek $(\% 99,4)$, eğitsel destek $(\% 98,7)$, hayatta kalma ve sorunlarla başa çıkma konusunda destek $(\% 96,1)$, güncel olaylar $(\% 94,5)$, çalışma ve yaşam boyu öğrenim $(\% 90,2)$, ruhsal gereksinimler $(\% 89,9)$, ekonomik bilgiler $(\% 81,7)$ ve mesleki eğitimdir $(\% 75,1)$. Emasealu'un (2018, s. 44) mahkûmlardan elde ettiği verilere göre, bilgi kaynaklarına erişimi etkileyen etmenler sırasıyla; dil engeli (\%50), materyalin formatı $(\% 49,3)$, kaynağın erişilebilirliği $(\% 44,7)$, kısitlama/sansür $(\% 43,1)$, gürültü $(\% 42,2)$, kullanıc1lardan kaynaklanan nedenler/kullanıcıların tutumu (\%30) ve eğitim seviyesidir $(\% 25,5)$.

Mahkûmların verdiği bilgilere göre kütüphanenin etkinliği değerlendirildiğinde, sözlük, ansiklopedi, bibliyografya, rehber, harita, atlas ve roman gibi önemli bilgi kaynaklarına erişilemediği sonucu ortaya çıkmıştır. El kitapları ve ders kitapları gibi sadece birkaç bilgi kaynağının zaman zaman erişilebilir olduğu, temel bilgi kaynaklarının çoğunun kolay erişilebilir olmadığını dile getiren bilgiler, kütüphanenin işlevselliğinin olmadığını göstermektedir. Ayrıca kütüphaneye erişim konusunda mahkûmlar tarafından sıklıkla ileri sürülen gerekçeler, cezaevi kuralları ve düzenlemelerinin çok katı olması $(\% 39,3)$, kütüphane materyallerinin ilgilenilen konularla ilgisiz olması ve bilgi gereksinimlerini karşılamaması (\%19), kütüphane ortamının elverişsizliği (\%17), kütüphane personelinin arkadaş canlısı olmaması $(\% 12,6)$ ve kütüphanenin hücrelerden uzak olması (\%12) biçimindedir (Emasealu, 2018, s. 43). Çalışmada, kütüphanenin bilgi gereksinimlerini karşılama ve rehabilitasyon bağlamında önemine vurgu yapılarak, devlet, cezaevi görevlileri ve tüm ilişkili paydaşların bu konuda duyarlı olması, mahkûmların taleplerinin karşılanması ve kütüphanenin güncel bilgi kaynakları ile desteklenmesi önerilmektedir (Emasealu, 2018, s. 46).

Ijiekhuamhen ve Aiyebelehin'in (2018) Nijerya'da Delta eyaletinde bulunan mahkûmların bilgi gereksinimleri ve bilgi davranışlarının araştırıldığı çalışmada anketler yolu ile mahkûmların bilgi gereksinimleri sorgulanmıştır. Çalışma için üretilen anket soruları 1154 mahkûma yönlendirilmiş ve 937 kişiden dönüş olmuştur. Soruları yanıtlayanların hepsi öncelikle nasıl serbest bırakılacaklarına dair mevzuat (\%100) ile aile ve yakınlarına (\%100) 
ilişkin bilgi gereksinimlerini dile getirmiştir. Bunu, sağlıkla ilgili duyulan bilgi gereksinimleri (\%87) ve finansal konular (\%83) izlemektedir. Diğer bilgi gereksinimleri ise sırasıyla; cezaevi kuralları ile ilgili bilgiler (\%76), güncel olaylar hakkında bilgiler (\%69), ruhsal, manevi ve ahlaki konular (\%45), cezaevinde mahkûm haklarına ilişkin konular (\%23), beceriler kazandıran bilgiler (\%13), okuryazarlık ve eğitim bilgileri (\%11) ve cezaevinden sonraki yaşama ilişkin bilgilerdir (\%10) (Ijiekhuamhen ve Aiyebelehin, 2018, s. 108). En fazla tercih edilen bilgi kaynakları ise sırasıyla; aile üyeleri ve arkadaşlar (\%95), radyo/televizyon (\%90), cezaevi müdürü ve görevlileri (\%66), cezaevini ziyaret eden STK'lar (\%57), avukatlar (\%47), kilise veya camiler (\%12), doktor ve hemşireler (\%10), kütüphane (\%8) ve gazetelerdir (\%2). Çevrim içi kaynaklara izin verilmediği için kullanımları söz konusu olmamıştır. Kütüphanenin çok düşük oranda kullanılması, mahkûmların büyük çoğunluğunun kütüphanenin oldukça yetersiz (\%72) ve yetersiz (\%28) olduğu yönünde görüş bildirmeleri ile örtüşmektedir (Ijiekhuamhen ve Aiyebelehin, 2018, s. 109).

Aynı çalışmada (Ijiekhuamhen ve Aiyebelehin, 2018, s. 109-110), bilgi kaynaklarına erişimi etkileyen etmenler sorgulandığında en fazla yakınılan unsurlar; aile üyeleri ve arkadaşlar ile ilişkilerin kısıtlanması (\%100), cezaevi çalışanlarının düşmanca tavırları (\%98), kütüphane materyallerinin elverişsizliği (\%95), cezaevinin rahatsızlık veren doğası ve koşulları (\%94) ve soru sorulacak kimsenin bulunamamasıdır (\%87). Bunu izleyen sorunlar; internete erişimin olmaması (\%80), yasal desteklere erişim konusunda yetersiz bütçe (\%53) ve cezaevi politikalarının yetersizliği ve uygunsuzluğudur (\%37). Çalışmada, internet ve çevrim içi kaynaklara erişim izni verilmesi, tüm mahkûm odalarına TV sağlanması vb. eylemlerle cezaevi kurallarının esnetilmesi, STK'ların bilgi erişimine ilişkin daha çok desteği ve devletin cezaevlerine daha çok özen göstermesi gibi öneriler sunulmaktadır (Ijiekhuamhen ve Aiyebelehin, 2018, s. 111).

Sambo ve Ojei (2018) tarafindan Güney Güney Nijerya'da (South South Nigeria) bulunan cezaevlerinden 356 kadın mahkûma yöneltilen ve 306 mahkûmdan yanıtların alındığı anket araştırması ile kadın mahkûmların bilgi gereksinimlerinin ve bu gereksinimlerin karşılanmasına ilişkin etmenlerin saptanması amaçlanmıştır. Mahkûmların çoğunluğunun (\% 70) eğitim düzeyinin düşük olduğu anlaşılmıştır (mahkûmların \% 37'si orta öğretim ve \%33'ü ilköğretim mezunudur). Çalışmadan elde edilen sonuç, mahkûmların bilgi gereksinimlerinin öncelik sırasıyla; tıbbi bilgiler (\%98), eğitim ve güvenlik bilgileri (\%97), cezaevi sonrası yaşamla ilişkili bilgiler ile ruhsal ve ahlaki bilgiler (\%86), finansal bilgiler (\%84), aile/arkadaşlara ilişkin konular (\%82) ve yasal konular hakkında bilgiler (\%72), cezaevine ilişkin haklarla ilgili bilgiler (\%61), çeşitli beceriler kazandıran bilgiler (\%36) ve diğer bilgiler (\%22) olduğunu göstermektedir (Sambo ve Ojei, 2018, s. 9). En çok başvurulan bilgi kaynakları, öncelik sırasıyla; hukuk danışmanlığı (\%73) ile aile/arkadaş çevresi ve cami ya da kiliselerdir (\%67). Bunun dışında bilgi edinmek için en fazla başvurulan kaynaklar, doktor ve hemşireler (\%58), cezaevi personeli (\%32), kitaplar, gazeteler ve dergiler (\%21), radyo ve televizyon yayınları (\%17), kütüphaneler (\%14) ve diğer kaynaklardır (\%10). Kütüphanelerin en son başvurulan kanal olmasının muhtemel nedeni hem cezaevleri hem de kütüphanelerin bütçe ve kaynak yetersizliğidir. Kadın mahkûmların bilgi gereksinimlerine ilişkin etmenler, öncelik sırasıyla en fazla kalabalık kaynaklı sorunlar, hijyen eksikliği ve cezaevlerinin düşük bütçelerinin ortaya koyduğu sonuçlardır (\%96). Bunu izleyen etmenler; ilaç ve sağlık desteği eksikliği (\%91), 
güvenlik eksikliği (\%89), serbest bırakılma sonrası konaklama sorunu (\%78), aile ve arkadaşlar ile etkileşim kurmak için zaman yetersizliği (\%77), cinsel istismar ile çok uzun süreli gözaltı (\%75), eğitim ve kadınlar için özel tedavi eksikliği (\%66), zihin sağlığı sorunları (\%61), yasadışı faaliyetler (\%55), hamile kadınları koruma politikalarının eksikliği (\%38) ve diğer problemlerdir (\%24) (Sambo ve Ojei, 2018, s. 10). Anılan sorunların giderilmesinde cezaevi politikalarının kadınların gereksinimlerini dikkate alarak düzenlenmesi, rehabilitasyon için önemli bir araç olan kütüphanelerin güncel materyallerle desteklenerek iyileştirilmesi, kadınların genel ve mesleki eğitimlerinin programlanması vb. öneriler sunulmaktadır (Sambo ve Ojei, 2018, s. 11).

Usman ve diğerlerinin (2019) Nijerya' da iki cezaevinde (Maiduguri ve Yola Cezaevi) 60 mahkûm ile yaptığı anket araştırması sonucunda mahkûmların en fazla güncel olaylar $(\% 46,7)$ konusunda bilgilere gereksinim duyduğunu göstermiş̧tir. Bunu izleyen konular sırasıyla; din $(\% 18,3)$, eğitim $(\% 10)$, sağlık (\%10), çeşitli becerilerin kazanımı $(\% 6,7)$, siyasi konular $(\% 5)$ ile spor ve eğlencedir $(\% 3,3)$. En fazla bilgi alınan kaynaklar ise sırasıyla cezaevi personeli $(\% 48,3)$ ve akraba/arkadaşlardır (\%31,7). Bunları, ibadet yerleri $(\% 11,6)$, kitap / gazete $(\% 6,7)$ ve televizyon $(\% 1,7)$ izlemektedir. Mahkûmların genel olarak edindikleri bilgi ile tatmin olup olmadıkları sorulduğunda ortaya çıkan sonuç, çoğunun $(\% 73,3)$ düşük ölçüde memnuniyetini göstermektedir. Yüksek düzeyde memnuniyet belirten mahkûmların oranı çok düşüktür (\%26,7). Bu durum, mahkûmların beklentileri ile aldıkları bilgilerin örtüşmemiş olma olasılığına işaret etmektedir. Çalışma aynı zamanda mahkûmların bilgi edinme haklarına ilişkin farkındalığının olmadığını ve bu durumun bilgi arama davranışları ile anlamlı bir ilişkisi olduğunu göstermiştir (Usman ve diğerleri, , 2019, s. 70-72).

\section{Sonuç}

Bilgi davranışı, kısmen içgüdüsel kısmen de öğrenilmiş eylemleri kapsayan ve bireyin tüm yaşantısına yayılan bir süreçtir. Bilgi gereksinimi ile başlayan bu süreç, birbirini etkileyen ve tamamlayan bir dizi kümeli eylemin toplamını ifade etmektedir. İnsan, doğumundan itibaren hayatta kalabilmek ve nitelikli bir yaşam sürdürebilmek için bilgiye gereksinim duyar. $\mathrm{Bu}$ bilgiler, temel gereksinimler ve gündelik yaşamla ilgili bilgilerden, eğitsel, kültürel, bilimsel ve entelektüel bilgilere kadar çok çeşitli kategorilerde değerlendirilebilir. Ancak bu kategorilerin hiçbiri diğerinden soyut değildir; her biri diğerleriyle etkileşmekte ve birbirini olumlu ya da olumsuz biçimde etkileyebilmektedir. Bilgi davranışı, yaşamsal değeri nedeniyle yalnız bilgi bilimi alanında değil aynı zamanda çok çeşitli disiplin ve alanlarda da sorgulanan (biyoloji, evrim, bilişim, antropoloji, sosyoloji, psikoloji, eğitim, ekonomi vb.) bir konudur. Tarihsel süreçte, bilgi davranışı konusu üzerine zihin yoran tüm araştırmacıların zaman zaman ortak yönleri zaman zaman da ayrılan özellikleri ile beraber çeşitli yaklaşımlar geliştirdikleri; bu davranışları anlamak kaygısıyla modeller ve kuramlar ürettikleri bilinmektedir.

Mahkûmların bilgi gereksinimleri temelde özgür vatandaşların bilgi gereksinimleriyle benzerlik göstermesine karşın içinde bulundukları koşullar nedeni ile kendine özgü bir yapıya sahiptir. Cezaevi kuralları, sağlık bilgileri, yasal haklar, serbest bırakılma koşulları, eğlence ve dinlenme gibi konularda bilgi edinme gereksinimleri, bu yapı içerisinde ön plana çıkmaktadır. Bilgi davranışları, bulundukları cezaevi ortam ve koşullarının (çevresel etmenler) oluşturduğu bilişsel, duyuşsal, ruhsal ve kültürel etkiler nedeni ile kendine özgü dinamikleri olan bir yapı 
sergiler. Öte yandan, bilgi davranışlarında en fazla dikkati çeken durum, cezaevi kültürünün yarattığı gruplaşmalar ve grup aidiyeti ile güvenlik vb. çeşitli kaygı ve korkuların bu davranışları biçimlendiren etkileridir. Cezaevi kültürünün beslediği güvensizlik duygusu, bilgi kaynağının güvenirliliği sorununu da pekiştirmekte; mahkûmun bilgi davranışı sağlıksız bir boyuta taşınabilmektedir.

Özgür vatandaşlardan farklı biçimde kurallar ve sınırlılıklarla çevrili bir yaşam sürdüren ve bu nedenle dezavantajlı gruplar kapsamında değerlendirilen mahkûmlara verilecek her türden destek, onların hem cezaevinde kaldıkları süre içindeki, hem de cezaevi sonrasındaki yaşamlarını daha nitelikli duruma getirecek; topluma yeniden katılmalarını kolaylaştıracaktır. $\mathrm{Bu}$ bağlamda, cezaevlerinin koşullarının iyileştirilmesi, cezaevi ortamı ve olanaklarının olası en yüksek düzeyde dış dünya ile benzerliğinin sağlanması oldukça önemlidir.

Mahkûmların bilgi edinme, eğitim, kişisel gelişim, sosyalleşme, dış dünyayla bağlantı kurabilme gibi gereksinimlerinin karşılanmasında destekleyici bilgi sistemleri/kütüphaneler, ilişkili kurum ve kuruluşlar ile iletişim ve güçlü rehabilitasyon programları çok önemlidir. Ancak bu yapının geliştirilmesi ve mevcut sorunların giderilmesinde tek başına kurumun (cezaevi) çabası yeterli değildir. Öncelikle, ülke düzeyinde adalet ve ilişkili mekanizmalar, eğitim ve kültür kurumları, gönüllü kuruluşlar, medya vb. kanalları ile mahkûmu ötekileştiren ön yargıları ortadan kaldıracak bir farkındalık ile anlayışın beslenmesi, köklü iyileştirmeleri sağlayacaktır. Bilgi davranışı, ağırlıklı olarak cezaevi ortam ve kültürünün oluşturduğu baskı unsurlarından arındırılan mahkûmun, hem kişisel, eğitsel ve kültürel gelişimini sağlaması ve kendini daha kolay gerçekleştirebilmesi hem de topluma değer katması kolaylaşacaktır.

Literatürümüzde cezaevi kütüphanelerinin durumuna ilişkin sınırlı sayıda ve güncelliğini yitiren kaynakların varlığı ile mahkûmların bilgi gereksinimleri ve bilgi davranışlarını sorgulayan çalışmaların eksikliği dikkati çeken bir durumdur. Cezaevi kütüphanelerinin ilişkili mevzuat ve düzenlemeler de dâhil günümüzdeki durumunu açığa çıkaran, mahkûmların bilgi gereksinimleri ile bilgi davranışlarını sorgulayan, onların eğitsel, kültürel, sosyal, eğlenceye yönelik vb. tüm gereksinimleri ile tercihlerine ilişkin bilgileri içeren kapsamlı ve güncel araştırmalara gereksinim duyulmaktadır. Yaşam biçimi ve koşulları ile özel bir kategoride ele alınması gereken mahkûmların yaşam kalitelerinin iyileştirilmesine katkıda bulunulması öncelikle insan haklarının gereğidir. Anılan konulara ilişkin bilimsel araştırmaların yanında üniversitelerde bilgi ve belge yönetimi lisans ve lisansüstü ders programlarına "dezavantajlı gruplar" çerçevesinde eklemeler yapılması, mahkûmları temsil eden çeşitli sosyal sorumluluk projeleri ile medyada ve toplumsal katmanlarda farkındalık oluşturulması, halk kütüphaneleri ile gönüllü kuruluş ve örgütlerin entegre biçimde destek vereceği plan, proje ve araştırmalarla cezaevi kütüphanelerine kitap bağışı da dahil pek çok konuda destek olunması önemli düzeyde yarar sağlayabilir. Ancak bu bağlamda iyileştirmeler yapılabilmesi için öncelikle bu konuların devlet kademesinde ele alınarak değerlendirilmesi, mevcut politikaların ve mevzuatın gözden geçirilmesi gerekmektedir. Konuya ilişkin sorunların gündeme taşınması için gerek akademik düzeyde gerek uygulama alanında meslek elemanlarının istekliliği ve iradesi önemlidir. 


\section{Kaynakça}

Agarwal, N. K. (2018). Exploring context in information behavior: Seeker, situation, surroundings and shared identities. San Rafael, California: Morgan \& Claypool Publishers.

Akerström, M.. (1988). The social construction of snitches. Deviant Behavior, 9(2), 155-167. doi: 10.1080/01639625.1988.9967776

Association of Specialized and Cooperative Library Agencies. (1992). Library standards for adult correctional institutions. Chicago, IL: American Library Association.

Ayhan, D. (2019, 3 Kasım). Cezaevlerinde kitap seferberliği başladı. Sözcü Hayat. Erişim adresi: https://www.sozcu.com.tr/hayatim/yasam-haberleri/cezaevlerinde-kitap-seferberligi-basladi/

Ayres, L. P. ve A. McKinnie (1916). The public library and the public schools. Cleveland, OH: Survey Committee of the Cleveland Foundation.

Bajić, M. (2015). Information needs and reading interests of prisoners. F. Pehar ve diğerleri (Ed.), 14th International Symposium on Information Scienceiçinde (s. 522-527). Glückstadt, Almanya: Verlag Werner Hülsbusch. doi: 10.5281/zenodo.17931

Biju, K. S. ve Johnson, E. (2018). A study on user satisfaction in prison libraries in Kerela. Kelpro Bulletin, 22(1), 71-79. Erişim adresi: http://dspace.cusat.ac.in/jspui/handle/123456789/13410

Bingman-Forshey, H. ve Gibbons, P. (2020) Behind the wall: Service challenges at a prison library. Public Services Quarterly, 16(1), 65-69. doi: 10.1080/15228959.2019.1677200

Bron, M. M. (2013). Exploration and contextualization through interaction and concepts (Doktora tezi). Erişim adresi: https://staff.fnwi.uva.nl/m.derijke/wp-content/papercite-data/pdf/bron-phd-thesis2013.pdf

Butdisuwan, S. (1999). Information services to the disadvantaged person: A challenge for information professionals in Thailand. 65th IFLA Council and General Conference'ta sunulan bildiri, Bangkok, Tayland. Erişim adresi: https://archive.ifla.org/IV/ifla65/papers/022-132e.htm

Campbell, D. K. (2005). The context of the information behavior of prison inmates. Progressive Librarian, 26, 18-32. Erişim adresi: http://www.progressivelibrariansguild.org/PL/PL26/018.pdf

Canning, C. ve Buchanan, S. (2019). The information behaviours of maximum security prisoners: Insights into self-protective behaviours and unmet needs. Journal of Documentation, 75(2), 417 434.

Case, D. O. (2002). Looking for information: A survey of research on information seeking, needs, and behavior. Amsterdam: Academic Press.

Chandani, J. G. (2019a). Enhancing library and Information resources and services for incarcerated persons: A survey in prison libraries in Sri Lanka. Journal of Humanities and Social Science, 24(12), 68-76.

Chandani, J. G. (2019b). Information needs, accessibility and utilization in prison library context of Sri Lanka. International Journal of Multidisciplinary Research and Development, 6(11), 150-155.

Chatterjee, A. (2017). Elements of information organization and dissemination. Cambridge, MA: Chandos Publishing.

Choo, C.W., Detlor, B. ve Turnbull, D. (2000). Web work: Information seeking and knowledge work on the World Wide Web. doi: 10.1007/978-94-015-9405-9

Clark, S. ve Erica, M. (2006). Library services to the incarcerated: Applying the public library model in correctional facilility libraries. London: Libraries Unlimited.

Clemmer, D. (1940). The prison community. New York: Holt, Rinehart and Winston.

Cooke, D. J., Baldwin, P. J. ve Howison, J. (1993). Psychology in prisons. London: Routledge. 
Crighton, D. A. ve Towl, G. J. (2008). Psychology in prisons (2. bs.). MA: Blackwell Publishing.

Çakmak, N. (2016). Lisans öğrencilerinin bilgi arama süreçleri ile ilgili kavramları, tutumları ve düşünceleri (Yayımlanmamış doktora tezi). Ankara Üniversitesi Sosyal Bilimler Enstitüsü Bilgi ve Belge Yönetimi Anabilim Dalı, Ankara.

Çölaşan, E. (2019, 5 Kasım). Cezaevleri kitap bekliyor. Sözcü. Erişim adresi: https://www.sozcu.com.tr/2019/yazarlar/emin-colasan/cezaevleri-kitap-bekliyor-5430836/

Dalkıran, Ö. (2019). A ̈̆ kuşă̆ının bilgi davranışı. İstanbul: Hiperlink.

Demir, G. (2011). Ceza infaz kurumu kütüphaneleri ve Türkiye'de durum (Yayımlanmamış doktora tezi), İstanbul Üniversitesi, Sosyal Bilimler Enstitüsü, İstanbul.

Demir, G. (2015a). Ceza infaz kurumu kütüphaneleri: Dünyada ve Türkiye'de durum. İstanbul: Hiperlink.

Demir, G. (2015b). Information behavior: an evolutionary instinct. Türk Kütüphaneciliği, 29(3),, 648653.

Drabinski, E. ve Rabina, D. (2015). Reference services to incarcerated people, Part I: Themes emerging from answering reference questions from prisons and jails. Reference \& User Services Quarterly, 55(1), 42-48. Erişim adresi: https://www.journals.ala.org/index.php/rusq/article/view/5798

Eikeland, O. J., Manger, T. ve Asbjørnsen, A. (Ed.). (2009). Education in Nordic prisons prisoners' educational backgrounds, preferences and motivation. Copenhagen: TemaNord.

Ellis, D. (2003). Information-seeking behaviour. J. Feather ve P. Sturges (Ed.). International encyclopedia of information and library science (2. bs.). içinde (s. 300-301). New York: Routledge.

Emasealu, H. U. (2018). Challenges of accessibility to information resources by prison inmates. International Journal of Knowledge Content Development \& Technology, 8(2), 37-48.

Emasealu, H. U. ve Popoola, S. O. (2016). Information needs and the enhancement of the psychological wellbeing of Nigerian prison inmates. Library Philosophy and Practice, 1365. Erişim adresi: http://digitalcommons.unl.edu/libphilprac/1365

Eze, J. U. (2015). Problems and prospects of providing library and information services to the prisoners in Nigeria. Library Review, 64(4/5), 285-304.

Eze, J. U. (2016). Information needs of prisoners in Southeast Nigerian prisons. Information Development. 32(3) 243-253. doi: 10.1177/0266666914538042

Gabhann, C. M. (2013). Irish travellers in prison: The unknown prisoners. Prison Service Journal, 206, 19-24. Erişim adresi:

https://www.crimeandjustice.org.uk/sites/crimeandjustice.org.uk/files/PSJ\%20March\%202013 $\% 20$ No.\%20206.pdf

Garner, J. (2017a) Australian prison libraries: A study of existing knowledge and recent findings. Journal of the Australian Library and Information Association, 66(4), 331-343.

Garner, J. M. (2017b). Experiencing the use of Australian prison libraries: A phenomenological study (Doktora tezi). Erişim adresi: https://researchbank.rmit.edu.au/eserv/rmit:162176/Garner.pdf

González-Teruel, A. ve Abad-García, M.F. (2007). Information needs and uses: An analysis of the literature published in Spain, 1990-2004. Library and Information Science Research, 29(1), 3046. doi: 10.1016/j.lisr.2007.01.001

Greenway, S. A. (2007). Library services behind bars. Bookmobile Outreach Services, 10(2), 43-64. Erişim adresi: http://citeseerx.ist.psu.edu/viewdoc/download?doi=10.1.1.606.5137\&rep=rep1\&type=pdf 
Haney, C. (2002). The psychological impact of incarceration: Implications for post-prison adjustment. Erişim adresi: https://www.urban.org/sites/default/files/publication/60676/410624-ThePsychological-Impact-of-Incarceration.PDF

Haney, C. (2012). Prison effects of in the age of mass incarceration. The Prison Journal, XX(X), 1-24. doi: $10.1177 / 0032885512448604$

Ijiekhuamhen, O. P. ve Aiyebelehin, J. A. (2018). Survey of the information needs and seeking behaviour of prisoners in Delta State, Nigeria. Journal of Applied Information Science and Technology, 11(2), 102-112. Erişim adresi: https://www.jaistonline.org/11vol2/12.pdf

Karaca, İ. (2015, 21 Nisan). Cezaevinde, Kitap ve Kütüphane ile İlgili Seminer. Bilgi ve Belge Yönetimi (BBY) Haber Portall. Erişim adresi: https://www.bbyhaber.com/bby/2015/04/21/cezaevindekitap-ve-kutuphane-ile-ilgili-seminer

Koç, O. (2018). Cezaevi kütüphaneleri: Kırşehir Açık Ceza İnfaz Kurumu Kütüphanesi örneği. Journal of Awareness, 3 (Özel Say1), 797-806. doi: 10.26809/joa.2018548689

Kongar, E. (1982). Ceza ve infaz kurumlarında kültür ve eğitim. Sanat Dergisi, 49(1), 2.

Kruppu, D. C. (1999). Information needs and information seeking behaviour of users in organizations. Information Studies, 5(1), 53-65.

Kundu, D. K. (2017). Models of information seeking behaviour: A comparative study. International Journal of Library and Information Studies, 7(4), 393-405.

Laltlanmawii, R. ve Verma, M. K. (2016). Information seeking behaviour of faculties and research scholars in School of Physical Sciences, Mizoram University, Aizawl: A Study. Journal of Library \& Information Science, 6(2), 265-274. Erişim adresi: http://irjlis.com/wpcontent/uploads/2016/08/8-IR-340-62.pdf

Learning \& Work Institute (2018). Offender rehabilitation. Erişim adresi: https://www.learningandwork.org.uk/our-work/life-and-society/offender-rehabilitation/

Lehmann, V. ve Locke, J. (2005). Guidelines for library services to prisoners. Hollanda: IFLA Headquarters.

Lithgow, S. (1999). Library and Information Services to disadvantaged users: The way forward. 65th IFLA Council and General Conference'ta sunulan bildiri, Bangkok,Tayland. Erişim adresi: http://origin-archive.ifla.org/IV/ifla65/papers/048-79e.htm

Ljodal, H. J. ve Ra, E. (2011). Prison libraries the Scandinavian way: An overview of the development and operation of prison library service. Library Trends, 59(3), 473-489.

Marco, G. A. (2012). The American public library handbook. Santa Barbara, CA: Libraries Unlimited.

McInerney, A. M. (2019). Irish prison libraries and prisoners' information needs: A survey. An Leabharlann: The Irish Library içinde. Erişim adresi: https://www.libraryassociation.ie/wpcontent/uploads/2018/11/An\%20leabharlann_22_1_0.pdf

McNinch, J. H. (1949). The Royal Society Scientific Information Conference, London, June 21-July 2, 1948, Bulletin of the Medical Library Association, 37(2), 136-141. Erişim adresi: https://www.ncbi.nlm.nih.gov/pmc/articles/PMC194801/pdf/mlab00244-0060.pdf

Ministry of Justice. (2011). Making prisons work: Skills for rehabilitation. Erişim adresi: https://dera.ioe.ac.uk/3384/7/11-828-making-prisons-work-skills-forrehabilitation_Redacted.pdf

Mortensen, H. (2015). Literacy matters! The literacy and reading needs of people with special needs. IFLA WLIC kongresinde sunulan bildiri, Cape Town, Güney Afrika. Erişim adresi: http://library.ifla.org/1231/1/099-moretensen-en.pdf 
Nicholas, D. (2000). Assessing information needs: Tools, techniques and concepts for the internet age (2. bs.). London: Aslib.

Omiunu, O. G. (2014). Conceptualizing information need: A phenomenological study. Journal of Library and Information Sciences, 2(2), 29-54. doi: 10.15640/jlis.v2n2a3

Omolola, A. G. (2015). Availability, accessibility and utilization of information resources and services for prison inmates in North Central States of Nigeria (Yayımlanmamış yüksek lisans tezi). Department of Library and Information Science, Faculty of Education, Ahmadu Bello University, Zaria, Nijerya.

Ordu, E. (2019, 20 Şubat). Cezaevi Kütüphanesine Kitap Bağışlandı, Savcı Mahkûmlara Seslendi: "En Çok Okuyan Eşiyle Görüşecek". Onedio. Erişim adresi: https://onedio.com/haber/cezaevikutuphanesine-kitap-bagislandi-savci-mahkumlara-seslendi-en-cok-okuyan-esiyle-gorusecek862454

Önal, H. İ. (1984). Cezaevlerine halk kütüphanesi hizmetleri. Türk Kütüphaneciliği, 33(3), 119-130. Erişim adresi: http://www.tk.org.tr/index.php/TK/article/view/1466/1458

Öner, A. (2003, 5 Aralık). Türkiye'de hapishane kütüphaneleri. Hapishaneler Konulu Sempozyum, Marmara Üniversitesi Göztepe Kampüsü Dr. İbrahim Üzümcü Konferans Salonu, İstanbul.

Özenç Uçak, N. (1997). Bilgi gereksinimi ve bilgi arama davranışı. Türk Kütüphaneciliği, 11 (4), 315325. Erişim adresi: http://www.tk.org.tr/index.php/TK/article/view/1059/1057

Paterline, B. A. ve Orr, D. (2016). Adaptation to prison and inmate self-concept. Journal of Psychology and Behavioral Science, 4(2), 70-79. doi: 10.15640/jpbs.v4n2a6

Ploch, A. (2012). Why dignity matters: Dignity and the right (or not) to rehabilitation from international and national perspectives. NYU Journal of International Law and Politics, 44, 889-949.

Rafedzi, E.R.K., Abrizah, A. ve Yu, H. (2016). The challenges in making library services accessible to incarcerated male juveniles in five correctional schools. Malaysian Journal of Library \& Information Science, 21(2), 95-110. doi: 10.22452/mjlis.vol21no2.7

Rafedzi, E. R. K., Zainal, N. K., Yu, H. ve Kamal, J. I. A. (2018). Barriers to access the information by male juvenile delinquents in Malaysia. International Journal of Academic Research in Progressive Education and Development, 7(3), 86-95. doi: 10.6007/IJARPED/v7-i3/4349

Reading, A. (2011). Meaningful information: The bridge between biology, brain, and behavior. New York: Springer.

Robson, A. ve Robinson, L. (2013). Building on models of information behaviour: Linking information seeking and communication. Journal of Documentation, 69(2), 169-193. doi: $10.1108 / 00220411311300039$

Sambo, A. S. ve Ojei, N. L. (2018). Women in prison and their information needs: South-South prison libraries perspective. Library Philosophy and Practice (e-journal), 1640. Erişim adresi: https://digitalcommons.unl.edu/libphilprac/1640

Sambo, A. S., Usman, S. A. ve Rabiu, N. (2017). Prisoners and their information needs: Prison libraries overview. Library Philosophy and Practice, 1467. Erişim adresi: http://digitalcommons.unl.edu/libphilprac/1467

Scott, C. (2016). Exploring information behaviour in the small world context (Yayımlanmamıs doktora tezi). Department of Computer and Information Science University of Strathclyde, Glasgow, İskoçya.

Spink, A. (2010). Information behavior: An evolutionary instinct. Dordrecht: Springer. 
Tarzaan, P. M., Chorun, M. T. ve Mbatsoron, V. (2015). Information needs and seeking behaviour of prisoners'at the medium security prison in Makurdi Local Government Area of Benue State. International Journal of Academic Library and Information Science, 3(7), 193-199.

Taylor, R. (1968). Question-negotiation and information seeking in libraries. College and Research Libraries, 29(3), 178-194. Erişim adresi: https://crl.acrl.org/index.php/crl/article/view/12027/13473

Umamaheswar, J. (2018). Studying homeless and incarcerated persons: A comparative account of doing field research with hard-to-reach populations. FQS, 19(3), Art. 24. Erişim http://www.qualitativeresearch.net/index.php/fqs/article/view/3053/4287

Usman, E. A., Istifanus, I. L. ve Audu, P. (2019). Awareness of right to information, needs and seeking behaviour of inmates in Maiduguri and Yola Prisons, Nigeria. International Journal of Library and Information Studies, 9(3), 65-74. Erişim adresi: http://www.ijlis.org/img/2019_Vol_9_Issue_3/65-74.pdf

Vandebosch, H. (2005). The perceived role of mass media use during incarceration in the light of prisoners' re-entry into society. Journal of Criminal Justice and Popular Culture, 12(2), 96-115.

Visher, C. A., Lattimore, P. K. (2007). Major study examines prisoners and their reentry needs NIJ Journal, 258, 30-33. Erişim adresi: https://www.ncjrs.gov/pdffiles1/nij/219603g.pdf

Wilhelmus, D. W. (1999) A new emphasis for correctional facilities' libraries. Journal of Academic Librarianship, 25(2), 114-120. doi: 10.1016/S0099-1333(99)80009-3

Wilson, T. D. (1994). Information needs and uses: Fifty years of progress? B. C. Vickery (Ed.). Fifty years of information progress: A Journal of Documentation review içinde (s. 15-51). London: Aslib.

Wilson, T. D. (1997). Information behaviour: An interdisciplinary perspective. Information Processing \& Management, 33(4), 551-572. doi: 10.1016/S0306-4573(97)00028-9

Wilson, T. D. (1999). Models in information behaviour research. Journal of Documentation, 55(3), 249270.

Wilson, T. D. (2000). Human information behavior. Special Issue on Information Science Research, 3(2), 49-55. Erişim adresi: http://www.inform.nu/Articles/Vol3/v3n2p49-56.pdf

Wilson, T. D. (2006). 60 years of the best in information research: On user studies and information needs. Journal of Documentation, 62(6), 658-670.

Worley, R. M. (2011). To snitch or not to snitch, that is the question: Exploring the role of inmate informants in detecting inappropriate relationships between the keeper and the kept. International Review of Law, Computers and Technology, 25, 79-82. doi: 0.1080/13600869.2011.594660

Yıldız, H. ve Özenç Uçak, N. (2014). Bireyselden ortak bilgi davranışına. Bilgi Dünyası, 15(1), 1-26.

Zamble, E. (1992). Behavior and adaptation in longterm prison inmates: Descriptive longitudinal results. Criminal Justice and Behavior, 19, 409-425. doi: 10.1177/0093854892019004005 


\section{Summary}

Since ancient times, information is regarded as an essential phenomenon and power for the existence and development of humanity and societies. Means and ways of accessing information, factors preventing or enabling the use of information became the subject of various studies in many disciplines. However, the common purpose of all inquiries, such as personality in psychology, examining consumer behavior, innovation studies, health communication studies, organizational decision making, and information requirements in information systems design, is to secure humanity's development and welfare. In a comprehensive definition, information behavior is the process of complex actions and interactions, beginning with the need for information due to various reasons and continuing until the information targeted is accessed. Besides originating from the subject and/or the object, these processes occurring between the subject and the object have many different dimensions as they may be surrounded by many factors such as physical, cognitive, spiritual, social, economic, educational, cultural, scientific and technological factors. Therefore, the information behavior of each individual or group should be examined, considering their distinctive characteristics and conditions. In this context, one of the most important questions to be asked is whether all individuals and groups have equal rights in terms of access to information and the sources and channels of information. Although it is said that all people are born equal, and all have equal rights to education, opportunities, and community participation, in the real world, there are some people who do not have these rights because of their physical, mental, and social conditions. Persons in such situations are also described as "disadvantaged." The term "disadvantaged" is used for individuals or groups of low status in a particular society due to their race, gender, ethnicity, economic status, language, geographical location, environment, education, and disability. This group which is the focus of interest of a special IFLA section (IFLA LSDP= Section of Libraries Serving Disadvantaged Persons) includes patients in hospitals, older adults in nursing homes and individual care facilities, those who cannot leave the house for various reasons, deaf people, people with physical, developmental or learning disabilities as well as prisoners. Individuals in prisons, like other citizens, have the right to education, training, and information. These rights are also guaranteed by international regulations. Education provides the acquisition of a wide range of knowledge and skills. Knowledge and skills regarding information behavior have an essential place as it positively affects the lifelong learning of prisoners and paves their way for a quality life. In this day and age in which information and information environments are rapidly growing and diversifying, the awareness of the researcher about the subject and the knowledge and skills he possesses in the process of information seeking behavior is also crucial as much as the reliability of these environments. Information behaviors of individuals and groups limited in benefiting from information sources due to various reasons (physical, mental, educational, social, economic, cultural, etc.) should be taken into consideration within the framework of their unique conditions.

This study aims to create awareness with a general theoretical framework regarding the information needs and information behaviors of the prisoners evaluated in the said category. To provide a basis for the study, detailed information on facts, concepts, and approaches related to information behaviors are provided. Then, in this context, the information needs and behaviors of the prisoners and the factors that shape them are discussed. In this research descriptive method in which the question of "what" is focused mainly on describing characteristics of the 
situation being studied is used. As mentioned above, foreign literature is consulted mainly because of limited domestic researches to the related area.

The findings of this study demonstrated that although the information needs of the prisoners are similar to the information needs of free citizens, they have a unique structure due to their conditions. When questioned about what information the prisoners needed the most, the emerging topics included prison rules, health information, legal rights, conditions of release, etc. Prisoners' information behavior exhibits a structure with unique dynamics due to the cognitive, affective, spiritual, and cultural influences that arise within the context of the prison environment and conditions (environmental factors). The most striking aspect of information behavior is the characteristics created by the prison culture. Struggling with anxiety and fear for security, being involved in particular groups common in prisons, in other words, being has to belong to a group, shape these behaviors substantially. The sense of insecurity fed by the prison culture reinforces the problem of the reliability of the information source, and the information behavior of the prisoner may become unhealthy. Support for prisoners considered to be in disadvantaged groups will increase their life quality both during and after their stay in prison and will help them rejoin society. For these reasons, it is vital to improve the conditions of prisons and to ensure that prison environments and resources are similar to those of the outside world at the highest possible level. However, the efforts of the institution (prison) alone to solve these problems by providing opportunities such as education, libraries, etc. and rehabilitation programs are not enough. First of all, cultivating an understanding which will eliminate prejudices marginalizing prisoners through channels such as national justice and related mechanisms, educational institutions, media, etc. will provide drastic improvements. The prisoner, whose information behavior made free from oppression, similar to a free citizen outside, will have an easier time both when developing personally and when joining society as a beneficial person for the universe. 